\title{
First Early Pliocene micromammal faunas from the Venta del Moro area (Cabriel Basin, Spain): new data on the Messinian dispersal of Debruijnimys
}

\author{
S. Mansino ${ }^{1 *}$, F.J. Ruiz-Sánchez ${ }^{1,2,3}$, L. de Luque ${ }^{4}$, P. Montoya ${ }^{1}$, L. Gibert ${ }^{5}$, J. Morales ${ }^{6}$, \\ J. Abella ${ }^{2,6}$, V.D. Crespo' ${ }^{1}$, G.R. Scott ${ }^{7}$ \\ ${ }^{1}$ Departament de Geologia, Àrea de Paleontologia, Universitat de València, Doctor Moliner 50, 46100 Burjassot, Spain. \\ ${ }^{2}$ Universidad Estatal Península de Santa Elena, Edificio INCYT, Km 1.5 Avenida Principal Santa Elena, \\ 240210 La Libertad, Ecuador. \\ ${ }^{3}$ L'Hort de Feliu, P. O. Box 8460, Alginet, Valencia, 46018, Spain. \\ ${ }^{4}$ Fundación Conjunto Paleontológico Teruel-Dinópolis, Edificio Dinópolis. Avda Sagunto s/n, Teruel 44002, Spain. \\ ${ }^{5}$ Departament de Geoquímica, Petrologia i Prospecció Geologica, Universitat de Barcelona, C/Martí i Franqués s/n, \\ 08028 Barcelona, Spain. \\ ${ }^{6}$ Institut Català de Paleontologia Miquel Crusafont, Universitat Autònoma de Barcelona, Edifici ICTA-ICP, Carrer \\ de les Columnes s/n, Campus de la UAB, Cerdanyola del Vallès, 08193 Barcelona, Spain. \\ ${ }^{7}$ Berkeley Geochronology Center, 2455 Ridge Road Berkeley, California 94709, USA. \\ e-mail addresses: samuel.mansino@uv.es (S.M.; *corresponding author),francisco.ruiz@uv.es (F.J.R-S.),luque@fundaciondinopolis.org \\ (L.L.),plinio.montoya@uv.es (P.M.),lgibert@ub.edu (L.G.),mcnm166@mncn.csic.es(J.M),juan.abella@gmail.com (J.A),vicente.crespo@ \\ uv.es (V.D.C.), gscott@bgc.org (G.S.)
}

Received: 1 August 2014 / Accepted: 1 June 2015 / Available online: 20 July 2015

\begin{abstract}
The localities of La Bullana 3 and LA Bullana 2B (Valencia, E Spain) have yielded remains of Apodemus gorafensis, Paraethomys aff. abaigari, Stephanomys dubari, Apocricetus barrierei, Sciuridae indet. and Asoriculus cf. gibberodon the former, and Apodemus gorafensis, Paraethomys aff. abaigari, Stephanomys dubari, Apocricetus barrierei, Sciuridae indet., Asoriculus cf. gibberodon, Castillomys gracilis, Occitanomys brailloni, Occitanomys sp., Paraethomys meini, Ruscinomys sp., Eliomys intermedius, Debruijnimys cf.julii and Atlantoxerus sp. the latter. Based on the study of these micromammal assemblages, we propose an Early Pliocene age (MN14) for both sites. The presence a gerbilid related to Debruijnimys julii in La Bullana 2B open new questions about the phylogenetic relationship between Debruijnimys species from the Miocene and Pliocene of the Iberian Peninsula. Furthermore, preliminary paleomagnetic data indicate an age between 4.997 Ma and 4.896 Ma for La Bullana 2B, and between 5.235 Ma and 4.997 Ma for La Bullana 3.
\end{abstract}

Keywords: Rodentia, Neogene, Ruscinian, Debruijnimys, Iberian Ranges, Iberian Peninsula

Resumen

Las localidades de La Bullana 3 y La Bullana 2B (Valencia, E Spain) han cedido restos de Apodemus gorafensis, Paraethomys aff. abaigari, Stephanomys dubari, Apocricetus barrierei, Sciuridae indet. y Asoriculus cf. gibberodon la primera, y Apodemus gorafensis, Paraethomys aff. abaigari, Stephanomys dubari, Apocricetus barrierei, Sciuridae indet., Asoriculus cf. gibberodon, Castillomys gracilis, Occitanomys brailloni, Occitanomys sp., Paraethomys meini, Ruscinomys sp., Eliomys intermedius, Debruijnimys cf. julii y Atlantoxerus sp. la segunda. Basándonos en el estudio de estas ascociaciones de micromamíferos, proponemos una edad correspondiente al Plioceno inferior (MN14) para ambos yacimientos. La presencia de un gerbílido relacionado con Debruijnimys julii en La Bullana 2B plantea nuevas preguntas acerca de la relación filogenética entre las especies de Debruijnimys del Mioceno y Plioceno. Además, datos paleomagnéticos preliminares indican una edad entre 4.997 Ma y 4.896 Ma para La Bullana 2B, y entre 5.235 Ma y 4.997 Ma para La Bullana 3.

Palabras clave: Rodentia, Neógeno, Rusciniense, Debruijnimys, Cordilleras Ibéricas, Penísula Ibérica

\section{Introduction}

Near the village of Venta del Moro (Valencia, Spain) part of the youngest sediments of the Cabriel Basin crop out in La
Bullana area. In this zone, the lower part of the limestone Unit that forms the uppermost deposits from this basin includes a significant proportion of detrital deposits, containing several levels with remains of freshwater gastropods and vertebrates. 
In the sections of La Bullana 2 and La Bullana 3, four new localities have been located: La Bullana 2A (LB2A), La Bullana 2B (LB2B), La Bullana 3 (LB3) and La Bullana 3A (LB3A). Only two of them, La Bullana 2B and La Bullana 3, have yielded a significant number of fossil remains.

The paleontological research of the Júcar-Cabriel area has been fruitful, with two important Late Turolian (or Ventian, sensu Morales et al., 2013) macromammal localities, namely Venta del Moro (Morales, 1984; Montoya et al., 2006) and La Portera (Lacomba et al., 1986), along with a number of micromammal sites (see references in Montoya et al., 2006; Benavent et al., 2008; Mansino et al., 2009; Ruiz-Sánchez et al., 2011). Venta del Moro (6.23 Ma) is one of the key localities for understanding the environmental and faunal changes occurred just before the Messinian Salinity Crisis (5.96-5.33 Ma), with more than a hundred identified species, six of which have been described in this site (Montoya et al., 2006; Morales et al., 2011; Mansino et al., in press). The new localities of La Bullana 2B and La Bullana 3 are stratigraphically higher than the eastern localities of Venta del Moro and Los Mingos (Montoya et al., 2006; Benavent et al., 2008; Mansino et al., 2009) (Figs. 1-2).

In this paper we describe the fossil rodent faunas from $\mathrm{La}$ Bullana 2B and La Bullana 3, and discuss their chronostratigraphical, biostratigraphical and paleobiogeographical implications.

\section{Material, methods and abbreviations}

Field work during 2005 and 2007 provided over $1200 \mathrm{~kg}$ of sediment from La Bullana 2B and 1,500 kg from La Bullana 3. After sieving these sediments, the recovered fossils were kept at the Museu de Geologia de la Universitat de València (MGUV), with the field labels LB2B- and LB3-, respectively. The nomenclature used in the descriptions of the teeth and the measurement methods are those of Martín-Suárez and Freudenthal (1993) for the family Muridae, Mein and Freudenthal (1971) for the Cricetidae, Daams (1981) and Freudenthal (2004) for the Gliridae, Cuenca-Bescós (1988) and Reumer and Van de Hoek Ostende (2003) for the Sciuridae, and Reumer (1984), modified by Furió (2007), for the insectivores. Measurements $(\mathrm{L} \mathrm{x} \mathrm{W)}$ ) are in millimetres and were taken on a Leica MZ75 binocular microscope, by means of displacement of a mechanical stage, connected to a Sony Magnescale measuring equipment. The lower teeth are indicated as $\mathbf{m} 1$, $\mathbf{m} 2$ and $\mathbf{m} 3$, the upper teeth as M1, M2 and M3, the premolars as p4 and P4, and the deciduous elements as $\mathrm{d} 4$ and D4.

Abbreviations.- AL2-C, Alcoy-2C; AL2-D, Alcoy-2D; CLC, Calicasas; L, Length; LB2B, La Bullana 2B; LB3, La Bullana 3; MN, European Neogene land mammal Units; MNA, Mina; PUR, Purcal; SCSIE (UV), Servei Central de Suport a la Investigació Experimental de la Universitat de València; THC, Tollo de Chiclana; TLW, talonid width; TRW, trigonid width; $\mathbf{W}$, Width.

\section{Geological setting}

The studied sites are located in the Cabriel Basin, a Neogene basin located between the Iberian platform to the North and Betic Cordillera to the South. The sedimentary infilling of the Cabriel Basin is mostly composed of Cenozoic limestones with detrital sediments (Fig. 1). The sedimentary record of this Basin contains several mammal sites ranging from the Late Aragonian to the Villanyian (MN7/8 to MN17) (see Ruiz- Sánchez et al. 2011 and references therein). The sites of La Bullana 2B and La Bullana 3 are located in the upper part of the Detritic Unit of Los Isidros, within the Venta del Moro-Villatoya Formation, according the stratigraphy described by Robles (1970) (Fig. 1). They are located approximately $3 \mathrm{~km}$ Southwest from the classic locality of Venta del Moro, about $10 \mathrm{~m}$ below La Molata, the top of the stratigraphic sequence (Fig. 2). However, the dip slope of La Bullana 2B and La Bullana 3 suggests that these localities may correspond to the same carbonated unit. The cross section of La Bullana 2, from where micromammal remains have been obtained, is mainly composed of detritic deposits, although it is crowned by a decametric layer of limestone. This outcrop includes several lignite levels and abundant fluvial sands, resting on red clays with intercalations of sandy channels. One kilometer Southeast from La Bullana 2B (30SXJ6394369), La Bullana 3 is located (30SXJ6404368), which probably represents an outcrop of equivalent deposits.

\section{Systematic Paleontology}

Order Rodentia Bowdich, 1821

Family Muridae Illiger, 1811

Genus Apodemus Kaup, 1826

Apodemus gorafensis Ruiz Bustos, Sesé, Dabrio, Peña and

Padial, 1984 (Fig. 3, 1-4)

Localities: LB2B, LB3.

Material: 7 m1 (LB2B-25, LB2B-88, LB2B-92, LB2B-183, LB3-2, LB3-3, LB3-30), 9 m2 (LB2B-35, LB2B-36, LB2B41, LB2B-105, LB2B-142, LB3-10, LB3-11 to LB3-13), 8 m3 (LB2B-44, LB2B-45, LB2B-114, LB2B-115, LB2B-200, LB2B-203, LB3-17, LB3-18), 8 M1 (LB2B-9, LB2B-13, LB2B-51, LB2B-129, LB2B-250, LB2B-258, LB3-19, LB320), 4 M2 (LB2B-20, LB2B-21, LB2B-136, LB3-22), 4 M3 (LB2B-214, LB2B-216, LB2B-219, LB3-24).

Measurements: see Table 1.

\section{Description:}

$m 1$ : The tma is large, round and central. Symmetrical anteroconid, its labial lobe connects with the metaconid. Welldeveloped labial cingulid, with a big round $\mathrm{c} 1$ and two or three accessory cuspids. One of the specimens has a hint of longitudinal spur. Big oval posterior heel, shifted towards the lingual side of the tooth. Roots are not preserved. 

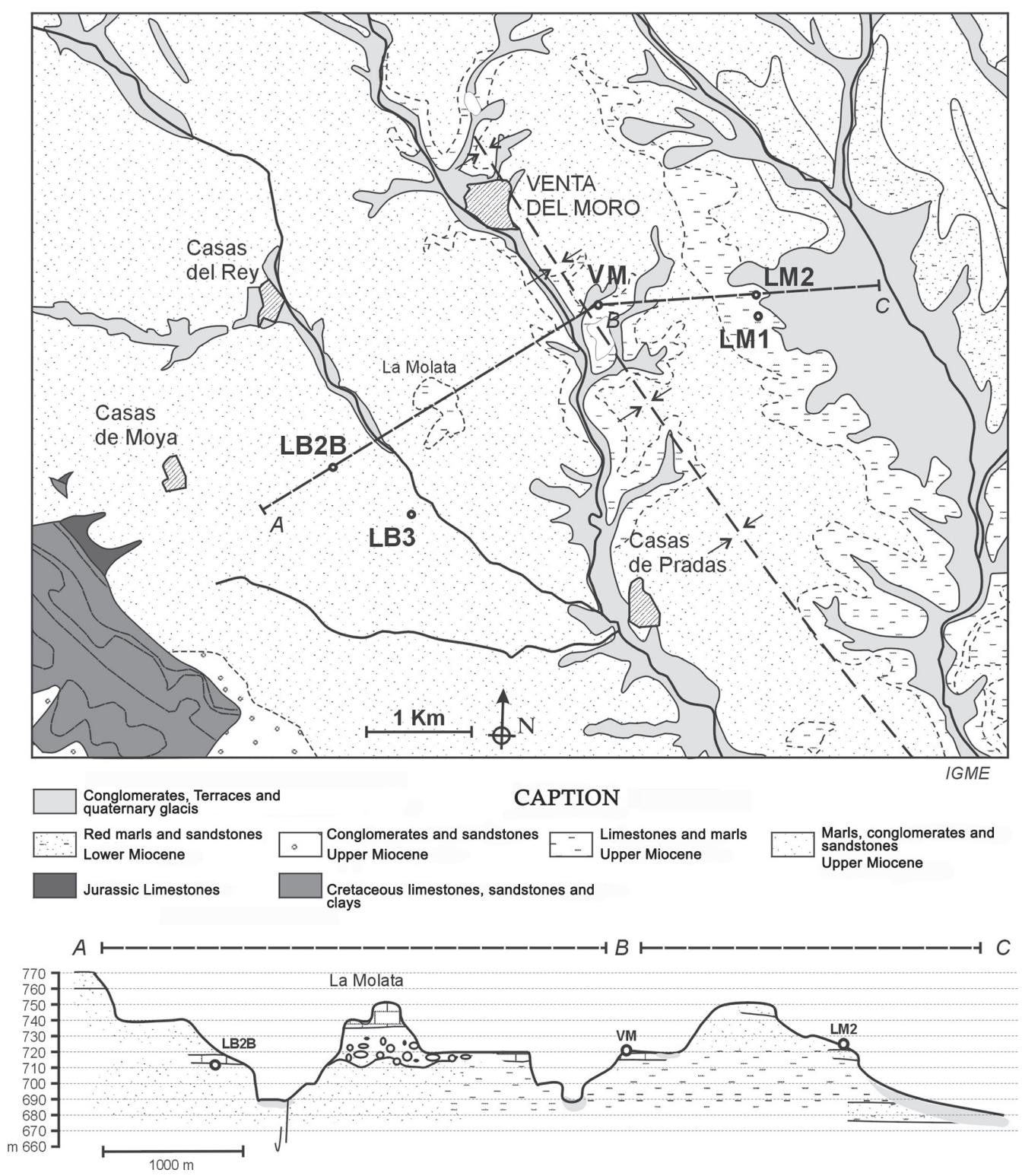

Fig. 1.- Geographic and geological setting of the surroundings of Venta del Moro (VM), showing the location of the sites Los Mingos 1 (LM1) (Benavent et al., 2008), Los Mingos 2 (LM2), La Bullana 2B (LB2B) and La Bullana 3 (LB3) (this paper).

m2: Big oval anterolabial cuspid. Well-developed labial cingulid, separated from the protoconid and hypoconid. There is a large round $\mathrm{c} 1$, except for one specimen in which this cuspid is much reduced, and one or two accessory cuspids. The posterior heel is large, round or oval. Roots are not preserved.

m3: Anterolabial cuspid reduced or absent. There is no longitudinal crest. One specimen has a small $\mathrm{c} 1$ connected to the labial side of the hypoconid-entoconid complex. Roots are not preserved.

M1: The t1 is displaced backwards. The connection between $\mathrm{t} 1$ and $\mathrm{t} 2$ is very low. There is neither $\mathrm{t} 1$ bis nor $\mathrm{t} 2 \mathrm{bis}$. The valley between $t 3$ and $t 6$ is very deep and wide. The $t 4$, t5, t6 and $t 9$ are connected. The $t 7$ is well developed, and there is a medium-sized 112 connected to the posterolabial side of t8. Roots are not preserved.
M2: The $\mathrm{t} 1$ is large, oval or round, and two specimens have a spur directed towards the $\mathrm{t} 4-\mathrm{t} 5$ connection. The $\mathrm{t} 3$ is reduced and isolated from the other cusps. The $\mathrm{t} 7$ is well developed and separated from $t 4$. The $t 6$ and $t 9$ are connected. The 12 is small, connected to the posterolabial part of $t 8$ and separated from 19 . Roots are not preserved.

M3: The $\mathrm{t} 1$ is isolated. The $\mathrm{t} 3$ is absent. The $\mathrm{t} 4, \mathrm{t} 5, \mathrm{t} 6$, $\mathrm{t} 8$ and t9 are connected. Roots are not preserved.

\section{Discussion:}

The presence of a large tma in the $\mathrm{m} 1$, well-developed labial cingulid in 1 and $\mathrm{m} 2$ and $\mathrm{t} 7$ in the uppermolars are typical traits of Apodemus. The specimens from LB2B and LB3 are larger than Apodemus atavus Heller, 1936 from TCH-1, 1B, 3 and 13 (Minwer-Barakar et al., 2005), PUR-7, PUR-13, CLC-3, CLC-3B, CLC-4B, AGU-1C and DHS-1 (García-Alix et al., 
W

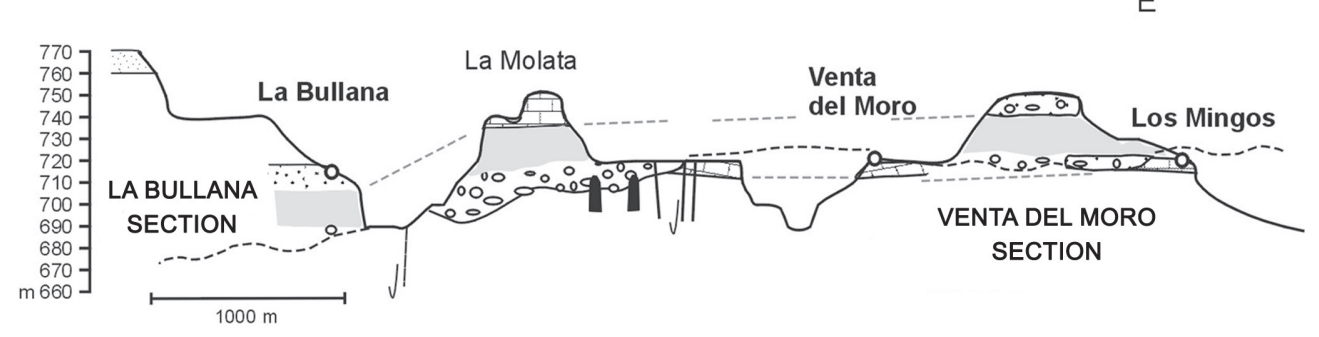

La Bullana 2

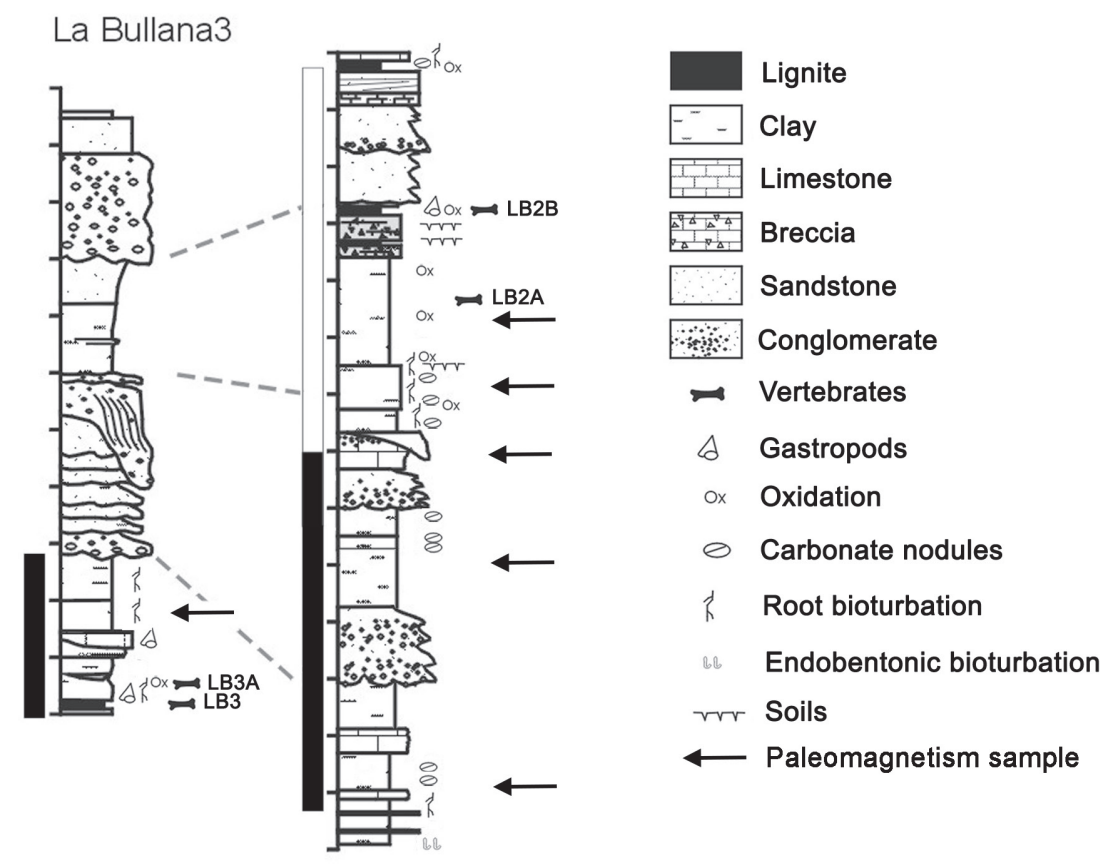

Fig. 2.- Geological sketch in the Venta del Moro area with location of the La Bullana and Venta del Moro sections, their correlation and the available paleomagnetic data: black, normal polarity; white, reversed polarity.

2008a) and smaller than Apodemus jeanteti Michaux, 1967 from Arquillo 3 and Villalba Alta (Adrover, 1986); this latter species further differs from A. gorafensis in the lack of tma in the m1. Apodemus gorafensis differs from its ancestor, Apodemus gudrunae van de Weerd, 1976, in the presence of a well-developed $\mathrm{t} 7$. This latter species is also slightly smaller than our specimens. In addition, Apodemus agustii MartínSuárez, 1988 differs from $A$. gorafensis in the partial stephanodonty of the upper molars, less-developed tma and lack of a pit in $\mathrm{ml}$ between the anteroconid, metaconid and protoconid. The size of the studied molars is consistent with $A$. gorafensis from its type locality, Gorafe A (Ruiz Bustos et al., 1984) and PUR-4, PUR-24A, PUR 25, PUR-25A, MNA-2 and MNA-4 (García-Alix et al., 2008a), Gorafe-3, Gorafe-4, Botardo-C and Huescar-1 (Martín-Suárez, 1988) and Alcoy 2C and 2D (Mansino et al., 2013), being also similar to $A$. aff gorafensis from PUR 23 (García-Alix et al., 2008a), Celadas 9, La Gloria 4 (Adrover et al., 1993) and Peralejos E (Adrover et al., 1988).

The development of the tma, labial cingulid and $\mathrm{t} 7 \mathrm{in}$ the specimens from La Bullana 2B and La Bullana 3 agrees with
A. gorafensis. There is a 19 (Fig. 3, 4) in two M3, while other two are much worn and this cusp cannot be observed. This cusp is absent in the fossil remains of $A$. gorafensis from the mentioned localities, with the exceptions of some specimens from PUR-23 and PUR-24A (García-Alix et al., 2008a).

Genus Castillomys Michaux, 1969

Castillomys gracilis van de Weerd, 1976 (Fig. 3, 5-7)

Locality: LB2B.

Material: 5 m1 (LB2B-90, LB2B-91, LB2B-94, LB2B-95, LB2B-188), 4 m2 (LB2B-106 to LB2B-109), 6 M1 (LB2B14, LB2B-125, LB2B-126, LB2B-204, LB2B-205, LB2B210) 1 M2 (LB2B-22), 1 M3 (LB2B-218).

Measurements: see Table 2.

\section{Description:}

m1: One specimen has a very small and low tma (Fig. 3, 5), absent in the rest. The anteroconid is symmetrical and connected to the protoconid-metaconid pair. There is a longitudinal spur and a narrow labial cingulid. The $\mathrm{c} 1$ is round 


\begin{tabular}{|c|c|c|c|c|c|c|}
\hline Element & Locality & Parameter & n & $\min$. & mean & $\max$. \\
\hline \multirow[t]{2}{*}{$\mathrm{m} 1$} & LB2B & $\mathrm{L}$ & 4 & 2.05 & 2.08 & 2.14 \\
\hline & & W & 4 & 1.26 & 1.31 & 1.35 \\
\hline \multirow[t]{4}{*}{$\mathrm{m} 2$} & LB2B & $\mathrm{L}$ & 5 & 1.49 & 1.54 & 1.57 \\
\hline & & W & 5 & 1.27 & 1.36 & 1.41 \\
\hline & LB3 & $\mathrm{L}$ & 4 & 1.49 & 1.52 & 1.58 \\
\hline & & W & 4 & 1.37 & 1.42 & 1.48 \\
\hline \multirow[t]{4}{*}{$\mathrm{m} 3$} & LB2B & $\mathrm{L}$ & 5 & 1.12 & 1.17 & 1.21 \\
\hline & & W & 5 & 1.03 & 1.08 & 1.12 \\
\hline & LB3 & $\mathrm{L}$ & 1 & - & 1.22 & - \\
\hline & & W & 1 & - & 1.08 & - \\
\hline \multirow[t]{3}{*}{ M1 } & LB2B & $\mathrm{L}$ & 1 & - & 2.22 & - \\
\hline & & W & 3 & 1.40 & 1.46 & 1.50 \\
\hline & LB3 & $\mathrm{L}$ & 2 & - & 1.57 & - \\
\hline \multirow[t]{4}{*}{ M2 } & LB2B & $\mathrm{L}$ & 3 & 1.53 & 1.57 & 1.63 \\
\hline & & W & 3 & 1.37 & 1.42 & 1.45 \\
\hline & LB3 & $\mathrm{L}$ & 1 & - & 1.70 & - \\
\hline & & W & 1 & - & 1.50 & - \\
\hline \multirow[t]{4}{*}{ M3 } & LB2B & $\mathrm{L}$ & 3 & 1.00 & 1.05 & 1.12 \\
\hline & & W & 3 & 0.94 & 1.02 & 1.08 \\
\hline & LB3 & $\mathrm{L}$ & 1 & - & 0.97 & - \\
\hline & & W & 1 & - & 1.01 & - \\
\hline
\end{tabular}

Table 1.- Measurements in millimeters of the teeth of Apodemus gorafensis from the localities La Bullana 2B and La Bullana 3. $\mathrm{n}=$ number of measurable specimens.

or oval and connected basally to the hypoconid. One molar has a small accessory cuspid. The posterior heel is small and lingually displaced. Roots are not preserved.

$m 2$ : Large anterolabial cuspid, connected to the labial cingulid. There is a small round $\mathrm{c} 1$. All specimens have a longitudinal spur. The posterior heel is small and oval. Roots are not preserved.

M1: The $\mathrm{t} 1$ is displaced backwards. All specimens have a small t 1 bis. The $\mathrm{t} 1$ is connected to the t4-t5 junction by a longitudinal crest. There is a small distal spur in $\mathrm{t} 3$, directed towards the $15-\mathrm{t} 6$ connection, and one specimen has a low labial longitudinal crest. The $\mathrm{t} 9$ is large. A small $\mathrm{t} 12$ is present. Roots are not preserved.

M2: The only available specimen is broken anterolabially. The $t 1$ is connected with the $t 4-t 5$ junction by a low crest. The $\mathrm{t} 3$ is small and isolated. Roots are not preserved.

M3: Isolated $t 1$. There is no $t 3$. The connection between $t 4$ and the t5-t6 junction is very low. The $t 8$ is isolated. Roots are not preserved.

\section{Discussion:}

Martín-Suárez and Mein (1991) recognized an increase in size from older to younger populations in the anagenetic line $C$. gracilis-C. crusafonti-C. rivas, in which all the Iberian populations from the Pliocene and Pleistocene could be encompassed. This means that the biometrics of the molars could be used as systematic criteria along the frequency percentages of some morphological characters (Martín-Suárez and Mein, 1991). The size of Castillomys from La Bullana

\begin{tabular}{ccccccc} 
Element & Locality & Parameter & $\mathrm{n}$ & min. & mean & max. \\
\hline $\mathrm{m} 1$ & LB2B & L & 5 & 1.35 & 1.40 & 1.47 \\
& & W & 5 & 0.88 & 0.90 & 0.93 \\
$\mathrm{~m} 2$ & LB2B & L & 4 & 1.02 & 1.06 & 1.12 \\
& & W & 4 & 0.93 & 0.95 & 0.98 \\
M1 & LB2B & L & 6 & 1.44 & 1.52 & 1.61 \\
& & W & 6 & 1.01 & 1.05 & 1.12 \\
M2 & LB2B & W & 1 & - & 1.21 & - \\
M3 & LB2B & L & 1 & - & 0.76 & - \\
& & W & 1 & - & 0.69 & - \\
\hline
\end{tabular}

Table 2.- Measurements in millimeters of the teeth of Castillomys gracilis from the locality La Bullana 2B. $n=$ number of measurable specimens.

\begin{tabular}{ccccccc} 
Element & Locality & Parameter & $\mathrm{n}$ & min. & mean & max. \\
\hline $\mathrm{m} 1$ & LB2B & L & 3 & 1.84 & 1.87 & 1.90 \\
& & $\mathrm{~W}$ & 4 & 1.25 & 1.28 & 1.31 \\
$\mathrm{~m} 2$ & LB2B & $\mathrm{L}$ & 2 & 1.45 & 1.50 & 1.55 \\
& & $\mathrm{~W}$ & 2 & 1.39 & 1.40 & 1.40 \\
$\mathrm{~m} 3$ & LB2B & $\mathrm{L}$ & 5 & 1.05 & 1.09 & 1.15 \\
& & $\mathrm{~W}$ & 5 & 0.97 & 1.02 & 1.06 \\
$\mathrm{M} 1$ & \multirow{2}{*}{ LB2B } & $\mathrm{L}$ & 3 & 1.96 & 2.05 & 2.11 \\
& & $\mathrm{~W}$ & 3 & 1.42 & 1.46 & 1.49 \\
$\mathrm{~N} 2$ & LB2B & $\mathrm{L}$ & 1 & - & 1.48 & - \\
& & $\mathrm{W}$ & 1 & - & 1.40 & - \\
\hline
\end{tabular}

Table 3.- Measurements in millimeters of the teeth of Occitanomys brailloni from the locality La Bullana $2 \mathrm{~B} . \mathrm{n}=$ number of measurable specimens.

2B is consistent with Castillomys gracilis van de Weerd, 1976 from its type locality (Caravaca), and Orrios-1 (Weerd, 1976), Moreda-1A and 1B, Rambla Seca-AB and Belmez-1 (Castillo, 1990), Botardo C and Gorafe 3 and 4 (Martín-Suárez, 1988), Mont-Hélène (Aguilar et al., 1986), Aldehuela and Villalba Alta (Adrover, 1986) and CLC-3, CLC-3B and PUR-13 (García-Alix et al., 2008a), but also agrees with some of the smallest measurements of Castillomys crusafonti Michaux, 1969 (Martín-Suárez and Mein, 1991; MinwerBarakat et al., 2005).

The morphology of the studied specimens agrees better with $C$. gracilis than with $C$. crusafonti, showing a longitudinal spur in $\mathrm{m} 1$ and a posterior spur in $\mathrm{t} 3$ of M1 instead of full longitudinal crests. However, 1 out of $6 \mathrm{M} 1$ does have a low longitudinal crest in $\mathrm{t} 3$, and all of them present a complete longitudinal crest connecting the $\mathrm{t} 1$ to the $\mathrm{t} 4-\mathrm{t} 5$, which is unusual in C. gracilis (Martín-Suárez and Mein, 1991). Moreover, the presence of a low crest in $\mathrm{t} 1$ of the M2 is rare in this species. However, based on the size of the specimens and the lack of longitudinal crests in the lower molars, we ascribe the sample from La Bullana 2B to C. gracilis.

Genus Occitanomys Michaux, 1969

Occitanomys brailloni Michaux, 1969 (Fig. 3, 8-13)

Locality: LB2B.

Material: $5 \mathrm{~m} 1$ (LB2B-53, LB2B-82, LB2B-93, LB2B96, LB2B-184), 2 m2 (LB2B-39, LB2B-100), 5 m3 (LB2B112, LB2B-113, LB2B-116, LB2B-119, LB2B-201), 4 M1 
(LB2B-11, LB2B-123, LB2B-124, LB2B-251) 1 M2 (LB2B135).

Measurements: see Table 3.

\section{Description:}

$m 1$ : Symmetrical anteroconid, connected to the protoconid-metaconid pair by a narrow crest. The labial cingulid is well developed. The $\mathrm{c} 1$ is large and round. Two specimens have a very small accessory cuspid. There is a longitudinal spur, which is reduced in two molars (Fig. 3, 8), more developed in other two, and developed into a very low longitudinal crest in one specimen (Fig. 3, 9). The posterior heel is small and oval. There are two roots.

$m 2$ : Trapezoidal outline, with the anterior side wider than the posterior one. Big round anterolabial cuspid, connected basally to the protoconid. The labial cingulid is reduced. The two available specimens have a longitudinal spur. The posterior heel is round. Roots are not preserved.

$m 3$ : There is neither anterolabial cuspid nor $\mathrm{c} 1$. Roots are not preserved.

M1: The connection between $\mathrm{t} 1$ and $\mathrm{t} 2$ is very low. The $\mathrm{t} 1$ bis is well developed. There is a small $\mathrm{t} 2$ bis (Fig. 3, 12), absent in one specimen. There is a low connection between $\mathrm{t} 1$ and the anterolingual side of $\mathrm{t} 5$. One specimen has a hint of distal spur in $\mathrm{t} 3$. The $\mathrm{t} 6$ and $\mathrm{t} 9$ are connected. The $\mathrm{t} 12$ is very small, barely a fold of the enamel. Roots are not preserved.

M2: The t1 is well developed, connected to the anterolingual side of $\mathrm{t} 5$ in one molar (Fig. 3, 13) and isolated in the other one. One specimen has a large t1 bis (Fig. 3, 13). Reduced $\mathrm{t} 3$, isolated from the other cusps. The $\mathrm{t} 9$ is well developed. Roots are not preserved.

\section{Discussion:}

The specimens from La Bullana 2B largely agree with the material of $O$. brailloni from Layna (type locality) described by Michaux (1969): $\mathrm{m} 1$ without tma and with the accessory cuspids less developed than Apodemus, M1 with t1 bis, a crest that connects $t 1$ to the posterior crown and a much reduced $\mathrm{t} 12$, and $\mathrm{M} 2$ with reduced $\mathrm{t} 3$ and well-developed $\mathrm{t} 1$ connected to the $t 5$ by a crest. Michaux (1969) also considered diagnostic the presence of a low longitudinal crest in $\mathrm{m} 1$, lower than in Stephanomys. Regarding this character, there seems to be a great variability among populations, and Adrover (1986) suggested an increase of the longitudinal crest in $\mathrm{m} 1$ and $\mathrm{m} 2$ through time. In the localities of the MN14 the longitudinal crest of $\mathrm{m} 1$ is developed in 3 out of 7 molars from Kardia and Ptolemais (Weerd, 1979), absent in the single $\mathrm{m} 1$ from
Gorafe A (Ruiz Bustos et al., 1984), and present in 1 out of 5 specimens from La Bullana 2B. In localities assigned to the early MN15, this crest is present in 2 out of 7 specimens from Arquillo 3 (Adrover, 1986), and absent in the two $\mathrm{m} 1$ from Vorio 3 (Hordijk and de Bruijn, 2009). In more recent localities, such as Layna, Nîmes (Michaux, 1969) and TCH1B (Minwer-Barakat et al., 2005) there is always a low longitudinal crest.

The distal crests in M1 show also a great variability. The specimens from Kardia (Weerd, 1979) have a crest on t1, and 1 out of 4 molars have also a crest on $\mathrm{t} 3$, while other two have a small spur. The single M1 from Gorafe A has a weak t1-t5 connection, and no trace of $\mathrm{t} 3 \mathrm{-t} 5$ connection (Ruiz Bustos et al., 1984). In the specimens from La Bullana 2B, the crest on t1 is high in one molar and much lower in the other one, while 2 out of 3 specimens have a much reduced spur on $\mathrm{t} 3$ (Fig. 3, 11). All specimens from Arquillo 3 have a crest on t1, and 4 out of 6 M1 have a spur on t3 (Adrover, 1986). In the Greek locality of Vorio 3 (Hordijk and de Bruijn, 2009) all M1 have a crest on $\mathrm{t} 1$, two molars have a spur on $\mathrm{t} 3$ and another one a developed crest. In Layna and Nîmes there is always a crest on $\mathrm{t} 1$, but the $\mathrm{t} 3$ has a spur (Michaux, 1969). The single M1 from TCH-1B has well-developed crests on t1 and $\mathrm{t} 3$ (Minwer-Barakat et al., 2005). The single specimen from Rambla Seca A1 also has developed crests, but lower than in the molar from TCH-1B (Minwer-Barakat, 2005). Each of the localities Cañada del Castaño 1 and Rambla Seca A2 yielded one $\mathrm{M} 1$, with a low crest on $\mathrm{t} 3$ and an isolated $\mathrm{t} 1$, while in the two M1 from Bélmez 1 the $\mathrm{t} 1$ has a low crest, and one specimen has a crest on $\mathrm{t} 3$, absent in the other one (Castillo, 1990; Martín-Suárez, 1988). The morphological variability of these connections is difficult to assess because of the scarcity of the remains in the localities where this species is found (Minwer-Barakat, 2005), although they seem to be slightly more developed in younger localities.

With respect to the size, the material from La Bullana 2B is similar in size to $O$. brailloni from other MN14 localities such as Ptolemais 1 and 3 and Kardia (Weerd, 1979), Gorafe A (Ruiz Bustos et al., 1984) and Vorio 1 (Hordijk and de Bruijn, 2009), and slightly smaller than the same taxon from MN15 localities such as Vorio 3 (Hordijk and de Bruijn, 2009), Arquillo 3 and Aldehuela (Adrover, 1986), Layna, Nîmes and Sête (Michaux, 1969), Cañada del Castaño 1 (Martín-Suárez, 1988), TCH-1B (Minwer-Barakat et al., 2005), Bélmez 1, Rambla Seca A1, A2 and A3, Moreda 1L-4 and the MN16 locality of Moreda 1B (Castillo, 1990). The scarce material from AL2-D (Mansino et al., 2013) is morphologically con-

Fig. 3.- (opposite page). Rodents from La Bullana 2B and La Bullana 3, Cabriel Basin, Spain. Apodemus gorafensis from LB2B and LB3. 1, right m2, LB3-10; 2, right M1, LB2B-9; 3, right M2, LB2B-21; 4, right M3, LB2B-219. Castillomys gracilis from LB2B. 5, left m1, LB2B-90; 6, right M1, LB2B-14; 7, left M3, LB2B-214. Occitanomys brailloni from LB2B. 8, left m1, LB2B-93; 9, left m1, LB2B-82; 10, left m2, LB2B-39 11, right m3, LB2B-112; 12, left M1, LB2B-123; 13, left M2, LB2B-135. Paraethomys meini from LB2B. 14, left m1, LB2B-29; 15, left m2, LB2B-193; 16, left m3, LB2B-198; 17, right M3, LB2B-138; Paraethomys aff. abaigari from LB2B. 18, left m1, LB2B-187; 19, left m2, LB2B-191; 20, left m3, LB2B3; 21, right M1, LB2B-128; 22, right M2, LB2B-134; Stephanomys dubari from LB2B and LB3. 23, right m1, LB2B-182; 24, left m3, LB2B-199; 25, left M1, LB2B-127; 26, left M1, LB2B-12; 27, left M2, LB2B-132; 28, left M3, LB3-24. Scale bar equals 1 mm. 


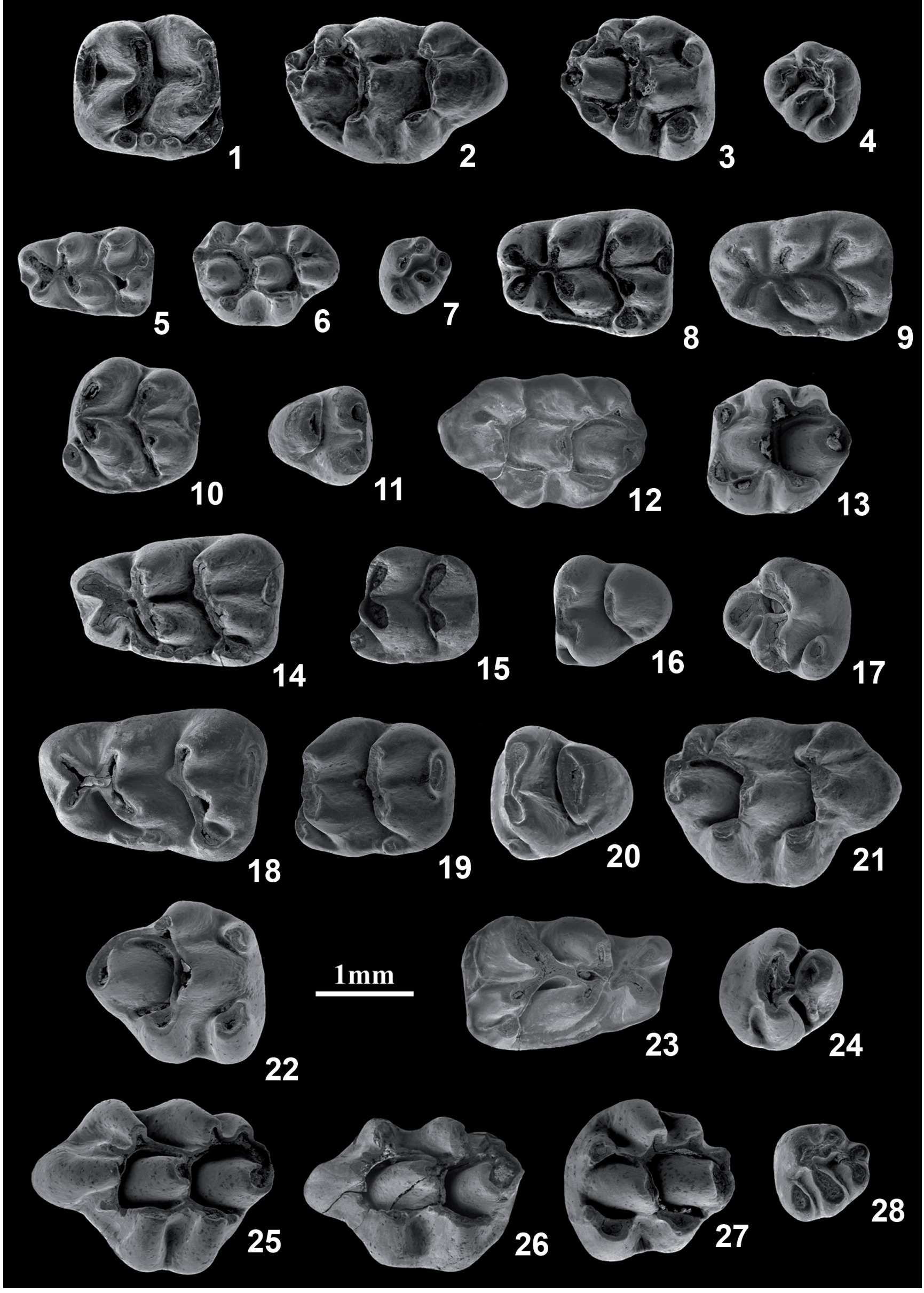


sistent with $O$. brailloni, but due to its extremely large size it is not clear if these specimens should be ascribed to this taxon or to a related form.

$O$. brailloni differs from $O$. alcalai Adrover, Mein and Moissenet, 1988, O. adroveri (Thaler, 1966), O. sondaari van de Weerd, 1976 and $O$. debruijni Sen, Jaeger, Dalfes, Mazin and Bochernes, 1989, by its larger size. It differs from $O$. montheleni Aguilar, Calvet and Michaux, 1984, by its smaller size. Some of the specimens from La Bullana 2B are close to the smallest values of $O$. brailloni, and therefore close to the largest dimensions of $O$. alcalai and within the size range of $O$. adroveri. $O$. sondaari differs from $O$. brailloni by the weak t6-t9 junction, the lesser development of the longitudinal crest in $\mathrm{m} 1$, the absence of $\mathrm{t} 1-\mathrm{t} 5$ connection in unworn specimens and by the absence of a crest on the $\mathrm{t} 3$ of the M1. $O$. alcalai differs from $O$. brailloni by the lesser development of longitudinal crests in the upper and lower molars. According to Michaux (1969), the longitudinal crest of $O$. adroveri is less developed than in $O$. brailloni, but as we noted before this character shows a great variability. The $\mathrm{m} 1$ of $O$. adroveri may present well-developed accessory cuspids. In the upper molars, the distal crests on $\mathrm{t} 1$ and $\mathrm{t} 3$ are usually more developed in $O$. brailloni than in $O$. adroveri, and the $\mathrm{t} 12$ is more reduced in O. brailloni. O. debruijni differs from $O$. brailloni by the reduced or absent $\mathrm{t} 3-\mathrm{t} 5$ connection and absence of $\mathrm{c} 1$ in $\mathrm{m} 2$, which may be present in O. brailloni (see material from Layna and Vorio 3 in Hordijk and de Bruijn, 2009 , plate 8).

\section{Occitanomys sp.}

Locality: LB2B.

Material: 1 M2 (LB2B-211).

Description:

M2: (1.38 x 1.32): The $\mathrm{t} 1$ is well developed, and connects basally with the $t 5$. The $\mathrm{t} 3$ is smaller than the $\mathrm{t} 1$ and isolated from the other cusps. The 19 is well developed. Roots are not preserved.

\section{Discussion:}

The general morphology of the specimen resembles $O c$ citanomys, but it is much smaller than the remains ascribed to $O$. brailloni. In addition, the t1-t5 connection is very low, while in O. alcalai it is usually higher. Because of the scarcity of the material that prevents the observation of more diagnostic features, we ascribe this molar to Occitanomys sp.

Genus Paraethomys Petter, 1968

Paraethomys aff. abaigari Adrover, Mein and Moissenet, 1988 (Fig. 3, 18-22)

Localities: LB2B, LB3.

Material: 5 m1 (LB2B-87, LB2B-99, LB2B-187, LB2B189, LB3-1), 13 m2 (LB2B-2, LB2B-34, LB2B-38, LB2B40, LB2B-42, LB2B-86, LB2B-103, LB2B-110, LB2B-

\begin{tabular}{|c|c|c|c|c|c|c|c|}
\hline Elemen & Species & Locality & Parameter & $\mathbf{n}$ & $\min$. & mean & $\max$. \\
\hline \multirow[t]{6}{*}{$\mathrm{m} 1$} & P. aff abaigari & LB2B & $\mathrm{L}$ & 1 & - & 2.36 & - \\
\hline & & & W & 3 & 1.49 & 1.52 & 1.57 \\
\hline & P. aff abaigari & LB3 & $\mathrm{L}$ & 1 & - & 2.36 & - \\
\hline & & & W & 1 & - & 1.54 & - \\
\hline & P. meini & LB2B & $\mathrm{L}$ & 8 & 2.12 & 2.18 & 2.26 \\
\hline & & & W & 9 & 1.38 & 1.43 & 1.46 \\
\hline \multirow[t]{6}{*}{$\mathrm{m} 2$} & P. aff abaigari & LB2B & $\mathrm{L}$ & 7 & 1.65 & 1.71 & 1.76 \\
\hline & & & W & 9 & 1.45 & 1.53 & 1.62 \\
\hline & P. aff abaigari & LB3 & $\mathrm{L}$ & 3 & 1.66 & 1.71 & 1.76 \\
\hline & & & W & 3 & 1.51 & 1.53 & 1.58 \\
\hline & P. meini & LB2B & $\mathrm{L}$ & 2 & 1.37 & 1.40 & 1.42 \\
\hline & & & W & 2 & 1.25 & 1.32 & 1.39 \\
\hline \multirow[t]{4}{*}{$\mathrm{m} 3$} & P. aff abaigari $i$ & LB2B & $\mathrm{L}$ & 7 & 1.43 & 1.47 & 1.51 \\
\hline & & & W & 7 & 1.25 & 1.31 & 1.37 \\
\hline & P. meini & LB2B & $\mathrm{L}$ & 5 & 1.29 & 1.31 & 1.35 \\
\hline & & & W & 6 & 1.15 & 1.20 & 1.28 \\
\hline \multirow[t]{3}{*}{ M1 } & P. aff abaigari & LB2B & $\mathrm{L}$ & 4 & 2.53 & 2.56 & 2.61 \\
\hline & & & W & 4 & 1.67 & 1.70 & 1.74 \\
\hline & P. meini & LB2B & W & 1 & - & 1.50 & - \\
\hline \multirow[t]{4}{*}{ M2 } & P. aff abaigari & LB2B & $\mathrm{L}$ & 5 & 1.79 & 1.87 & 1.96 \\
\hline & & & W & 6 & 1.60 & 1.67 & 1.73 \\
\hline & P. meini & LB2B & $\mathrm{L}$ & 1 & - & 1.56 & - \\
\hline & & & W & 2 & 1.47 & 1.48 & 1.49 \\
\hline \multirow[t]{4}{*}{ M3 } & P. aff abaigari & LB2B & $\mathrm{L}$ & 4 & 1.23 & 1.29 & 1.38 \\
\hline & & & W & 4 & 1.23 & 1.27 & 1.34 \\
\hline & P. meini & LB2B & $\mathrm{L}$ & 1 & - & 1.16 & - \\
\hline & & & $\mathrm{W}$ & 1 & - & 1.18 & - \\
\hline
\end{tabular}

Table 4.- Measurements in millimeters of the teeth of Paraethomys aff. abaigari and P. meini from the localities La Bullana 2B and La Bullana $3 . \mathrm{n}=$ number of measurable specimens.

191, LB3-7 to LB3-9, LB3-14), 7 m3 (LB2B-3, LB2B-47, LB2B-48, LB2B-118, LB2B-121, LB2B-195, LB2B-197), 6 M1 (LB2B-4, LB2B-15, LB2B-128, LB2B-206, LB2B-208, LB2B-209), 6 M2 (LB2B-17, LB2B-18, LB2B-130, LB2B134, LB2B-212, LB2B-213), 4 M3 (LB2B-139, LB2B-140, LB2B-215, LB2B-217).

Measurements: see Table 4.

\section{Description:}

$m 1$ : One molar has a very small cingulid ridge between the lobes of the anteroconid (Fig. 3, 18) and another one shows a low and small tma. The anteroconid is slightly asymmetrical. The anteroconid and the protoconid-metaconid pairs are connected by a narrow crest, which has an enamel funnel in one specimen. There is a longitudinal spur. The labial cingulid is moderately developed, with a large oval $\mathrm{c} 1$ and one or two accessory cuspids. The posterior heel is variable in size and shape, and lingually displaced. Roots are not preserved.

$m 2$ : Well-developed anterolabial cuspid, connected basally to the protoconid and the labial cingulid. A c1 variable in size and an accessory cuspid may be present. There is a longitudinal spur in 9 out of 11 specimens. The posterior heel is reduced in some molars, while others have a medium sized cuspid. Roots are not preserved. 
m3: The anterolabial cuspid is reduced in two specimens and absent in five. The hypoconid-entoconid complex is separated from the protoconid-metaconid pair. One of the specimens presents a small $\mathrm{cl}$ attached to the labial side of the posterior complex. Roots are not preserved.

M1: The connection between $\mathrm{t} 1$ and $\mathrm{t} 2$ is lower than the connection between $\mathrm{t} 2$ and $\mathrm{t} 3$. The $\mathrm{t} 2$ and $\mathrm{t} 3$ are very close together. Two specimens have a very low crest connecting $\mathrm{t} 1$ with the posterolingual side of $\mathrm{t} 5$. The spur in $\mathrm{t} 3$ is always present, small in two specimens and more developed in other two. The $t 9$ is well developed. The connection between $t 4$ and t8 is low. There is a small t12. Roots are not preserved.

M2: Isolated $\mathrm{t} 1$ and $\mathrm{t} 3$. The $\mathrm{t} 9$ may be absent (2), reduced (2) or developed (1). A much reduced t12 is present in two specimens. Roots are not preserved.

M3: The $\mathrm{t} 1$ is large and isolated, while $\mathrm{t} 3$ is absent. The $\mathrm{t} 8$ is connected with the $\mathrm{t} 4-\mathrm{t} 5-\mathrm{t} 6$ junction. Roots are not preserved.

\section{Discussion:}

Different species of Paraethomys are recognized in MN14 localities from the Iberian Peninsula: the small sized P. mei$n i$ (Michaux, 1969), and the larger P. abaigari and P. aff. abaigari, which have more developed distal spurs in the upper molars. Adrover et al. (1993) identified two species of Paraethomys in La Gloria 4 and Celadas 1 and 9, P. meini and P. anomalus (Bruijn, Dawson and Mein, 1970). These two species were morphologically very similar, and differed mainly in their size. Later, García-Alix et al. (2008a) ascribed the big-sized specimens from PUR-13 and CLC-5A to $P$. aff. abaigari, a form related to $P$. abaigari but slightly smaller, and considered the big-sized Paraethomys from La Gloria 4 and Celadas 9 to belong to the same taxon. Slightly older assemblages of Paraethomys, like the rich population from PUR-4, show a wide size range but, due to the impossibility to discriminate two clusters in this population, García-Alix et al. (2008a) ascribed that sample to P. meini, considering unlikely the coexistence of two Paraethomys species in that locality.

The specimens from La Bullana 2B and La Bullana 3 are similar in size to $P$. aff. abaigari from CLC-5A and PUR13 (García-Alix et al., 2008a), Celadas 9 and La Gloria 4 (Adrover et al., 1993), slightly smaller than $P$. aff. abaigari from AL2-C and AL2-D (Mansino et al., 2013), and clearly smaller than P. abaigari from Villalba Alta (Adrover et al., 1988). These molars are larger than P. meini from Sète (type locality), Layna, Nîmes, La Juliana, Arquillo III, Villalba Alta, Perpignan, Aldehuela, Orrios (Adrover, 1986), Villalba Alta Río, Peralejos E (Adrover et al., 1988), Celadas 9 and La Gloria 4 (Adrover et al., 1993), PUR-3, 4, 7 and 13, CLC-3, 3A, 4A, 4B, 5A, CAC-11,BRA-5B, DHS-1, 4A, 4B, 15B, 16 and MNA-4 (García Alix et al., 2008b) and Rambla de Chimeneas 3 (Minwer-Barakat et al., 2009a), P. anomalus from Maritsa and P. miocaenicus from Khendek el Ouaich (Adrover, 1986), considered synonyms of $P$. meini by several authors (van de Weerd, 1976; Adrover, 1986; Castillo, 1990;
Minwer-Barakat, 2005; García-Alix, 2006, García-Alixet et al., 2008a)

The development of distal spurs on the $\mathrm{t} 1$ and $\mathrm{t} 3$ of the M1 also agrees with $P$. abaigari rather than with P. meini. For these reasons, we ascribe the studied material to $P$. aff. abaigari.

Paraethomys meini (Michaux, 1969) (Fig. 3, 14-17)

Locality: LB2B.

Material: $12 \mathrm{~m} 1$ (LB2B-1, LB2B-26, LB2B-29 to LB2B33, LB2B-83, LB2B-85, LB2B-89, LB2B-185, LB2B-186), $2 \mathrm{~m} 2$ (LB2B-100, LB2B-193), $6 \mathrm{~m} 3$ (LB2B-46, LB2B50, LB2B-120, LB2B-122, LB2B-194, LB2B-198), 3 M1 (LB2B-16, LB2B-52, LB2B-84), 2 M2 (LB2B-19, LB2B131), 1 M3 (LB2B-138).

Measurements: see Table 4.

\section{Description:}

$m 1$ : one specimen has a very low and small tma. The anteroconid is slightly asymmetrical. The anteroconid and the protoconid-metaconid pair are connected by a narrow crest. Three specimens have a funnel of enamel in the connection between the anteroconid and the protoconid-metaconid (Fig. $3,14)$. In 8 out of 11 teeth there is a weak longitudinal spur. The labial cingulid is moderately developed, with a large oval c1 and one or two accessory cuspids, variable in size. Roots are not preserved.

$m 2$ : Well-developed anterolabial cuspid, connected basally to the protoconid and the labial cingulid. A small $\mathrm{c} 1$ is present in one specimen. There are no accessory cuspids. In 2 out of 3 specimens there is a longitudinal spur. The posterior heel is large in two molars and more reduced in another one. Roots are not preserved.

m3: One specimen has a small anterolabial cuspid, absent in the others. The hypoconid-entoconid complex is separated from the anterior protoconid-metaconid pair. A small crestshaped $\mathrm{c} 1$ is present in two molars. Roots are not preserved.

M1: All specimens are broken posteriorly. One specimen has two small cusps attached to the anterior side of $\mathrm{t} 2$. The $\mathrm{t} 1$ has a distal spur, developed into a very low crest in one of the specimens. There is a spur on the $\mathrm{t} 3$. Roots are not preserved.

M2: The dentine is almost completely lost in both molars. Isolated $t 1$ and $t 3$. The $t 9$ is slightly developed, and there is no t12. Roots are not preserved.

M3: The $\mathrm{t} 1$ is large and isolated. Absent $\mathrm{t} 3$. The $\mathrm{t} 8$ is connected to the t4-t5-t6 junction. Roots are not preserved.

\section{Discussion:}

Together with the large $P$. aff. abaigari, a small form of Paraethomys occurs in La Bullana 2B. The coexistence of two species of Paraethomys differing mainly in size has been recorded in several Pliocene localities from the Teruel and Granada Basins (Adrover, 1986; Adrover et al., 1988, 1993; García-Alix et al., 2008a), as well as in the French site of 
Sète (type locality of P. meini, Michaux, 1969). When both forms appear together, the size of $P$. meini is usually very small (García-Alix, 2006). The size of the specimens from La Bullana 2B is similar to $P$. meini from Sète, Layna, Nîmes, La Juliana, Arquillo III, Villalba Alta, Perpignan, Aldehuela, Orrios (Adrover, 1986), Villalba Alta Río, Peralejos E (Adrover et al., 1988), Celadas 9 and La Gloria 4 (Adrover et al., 1993), PUR-3, 4, 7 and 13, CLC-3, 3A, 4A, 4B, 5A, CAC-11,BRA5B, DHS-1, 4A, 4B, 15B, 16 and MNA-4 (GarcíaAlix et al., 2008b) and Rambla de Chimeneas 3 (Minwer-Barakat et al., 2009a), P. anomalus from Maritsa and P. miocaenicus from Khendek el Ouaich (Adrover, 1986).

The only morphological character used to distinguish $P$. meini from $P$. abaigari is the development of distal spurs in the upper molars, more prevalent in the latter species (Adrover et al., 1993). The three M1 from La Bullana 2B show spurs on the $\mathrm{t} 1$ and $\mathrm{t} 3$, which is unusual in $P$. meini, although in some localities like Peralejos E the presence of spurs in t1 and especially t3 is quite common (Adrover et al., 1993).

Genus Stephanomys Schaub, 1938

Stephanomys dubari Aguilar, Michaux, Bachelet, Calvet and Faillat, 1991 (Fig. 3, 23-28)

Localities: LB2B, LB3.

Material: 5 m1 (LB2B-27, LB2B-28, LB2B-97, LB2B-98, LB2B-182), 5 m2 (LB2B-37, LB2B-101, LB2B-102, LB2B104, LB2B-111), 4 m3 (LB2B-49, LB2B-117, LB2B-196, LB2B-197), 4 M1 (LB2B-10, LB2B-12, LB2B-127, LB2B207), 5 M2 (LB2B-23, LB2B-132, LB2B-133, LB2B-252, LB3-21), 3 M3 (LB2B-24, LB2B-137, LB2B-249).

Measurements: see Table 5.

\section{Description:}

$m 1$ : Slightly asymmetrical anteroconid, connected to the protoconid and metaconid. The labial cingulid is low and narrow. There is a well-developed longitudinal crest that connects the posterior cuspids to the connection of the protoconid-metaconid pair. There is a well-developed oval $\mathrm{c} 1$. The posterior heel is lingually displaced, ranging from oval to laminar. Two roots.

$m 2$ : Large and high anterolabial cuspid, connected to the protoconid and to a narrow labial cingulid. The longitudinal crest is lingually displaced towards the metaconid. There is neither $\mathrm{c} 1$ nor accessory cuspids. The posterior heel is large and oval. Roots are not preserved.

m3: Small and low anterolabial cuspid, connected to the protoconid. The longitudinal crest is complete (Fig. 3, 24). There are two roots.

M1: The $\mathrm{t} 1$ is slightly displaced backwards. There are small $\mathrm{t} 1 \mathrm{bis}$ and $\mathrm{t} 2 \mathrm{bis}$, more developed in one of the specimens (Fig. 3, 25). The posterior crest on the $\mathrm{t} 1$ is high and well developed in two specimens (Fig. 3, 25), and very low in other two (Fig. 3, 26), while the posterior crest on the $\mathrm{t} 3$ is high

\begin{tabular}{ccccccc} 
Element & Locality & Parameter & n & min. & mean & max. \\
\hline $\mathrm{m} 1$ & LB2B & L & 5 & 2.07 & 2.16 & 2.27 \\
& & W & 5 & 1.29 & 1.31 & 1.44 \\
$\mathrm{~m} 2$ & LB2B & L & 5 & 1.51 & 1.62 & 1.70 \\
& & W & 5 & 1.46 & 1.51 & 1.58 \\
$\mathrm{~m} 3$ & LB2B & L & 3 & 1.25 & 1.31 & 1.37 \\
& & W & 3 & 1.21 & 1.24 & 1.28 \\
M1 & LB2B & L & 4 & 2.30 & 2.46 & 2.69 \\
& & W & 4 & 1.58 & 1.74 & 1.83 \\
M2 & LB2B & L & 3 & 1.58 & 1.74 & 1.88 \\
& & W & 3 & 1.70 & 1.73 & 1.76 \\
& LB3 & L & 1 & - & 1.72 & - \\
& & W & 1 & - & 1.63 & - \\
M3 & LB2B & L & 2 & 1.15 & 1.25 & 1.36 \\
& & W & 2 & 1.13 & 1.22 & 1.31 \\
\hline
\end{tabular}

Table 5.- Measurements in millimeters of the teeth of Stephanomys dubari from the localities La Bullana $2 \mathrm{~B}$ and La Bullana 3. $\mathrm{n}=$ number of measurable specimens.

in all specimens. The t12 is highly reduced. Roots are not preserved.

M2: The $\mathrm{t} 1 \mathrm{has}$ a small $\mathrm{t} 1$ bis attached to its anterior side (Fig. 3, 27). In unworn specimens, the posterior crest of t1 is complete in two molars and low in another two, while the posterior crest on the $\mathrm{t} 3$ is complete in two specimens, low in one and absent in another one. The 112 is reduced in one molar and well developed in another one (Fig. 3, 27). There are three roots.

M3: The $t 1$ is connected basally to $t 5$. The $t 3$ is absent. The $\mathrm{t} 4$, t5 and t 6 are connected to $\mathrm{t} 8$. One specimen has a $\mathrm{t} 9$ (Fig. $3,28)$. Roots are not preserved.

\section{Discussion:}

The great height of the crown, high longitudinal crests in the lower molars (Fig. 3, 23-24) and crests or spurs in t1 and $t 3$ of the upper molars (Fig. 3, 25-27) indicate that these specimens belong to the genus Stephanomys. These molars are smaller, lower crowned and have a less pronounced stephanodonty than the Stephanomys identified in the Pliocene and Pleistocene (see Minwer-Barakat et al., 2011 and references therein).

The studied specimens share some characters with $S$. cordii Ruiz Bustos, 1986, like the t1 slightly more posterior than the t3 in M1 (Fig. 3, 25-26) and one $\mathrm{m} 3$ with the longitudinal crest connected to the protoconid (Fig. 3, 24). However, although some molars have the size and morphology of S. cordii (Fig. 3, 25) most of them agree better with $S$. dubari Aguilar, Michaux, Bachelet, Calvet and Faillat, 1991, with low crests connecting t1 and $\mathrm{t} 5$ in M1 (Fig. 3, 26), low or absent longitudinal crests in $\mathrm{M} 2$ and a smaller size. The presence of specimens similar to $S$. cordii has been reported in some populations of $S$. dubari, such as in the lower Ruscinian sites of PUR-4 and PUR-13 in the Granada Basin (García-Alix et al., 2008a). The material from La Bullana 2B and La Bullana 3 has been directly compared with $S$. cordii from AL2-C 


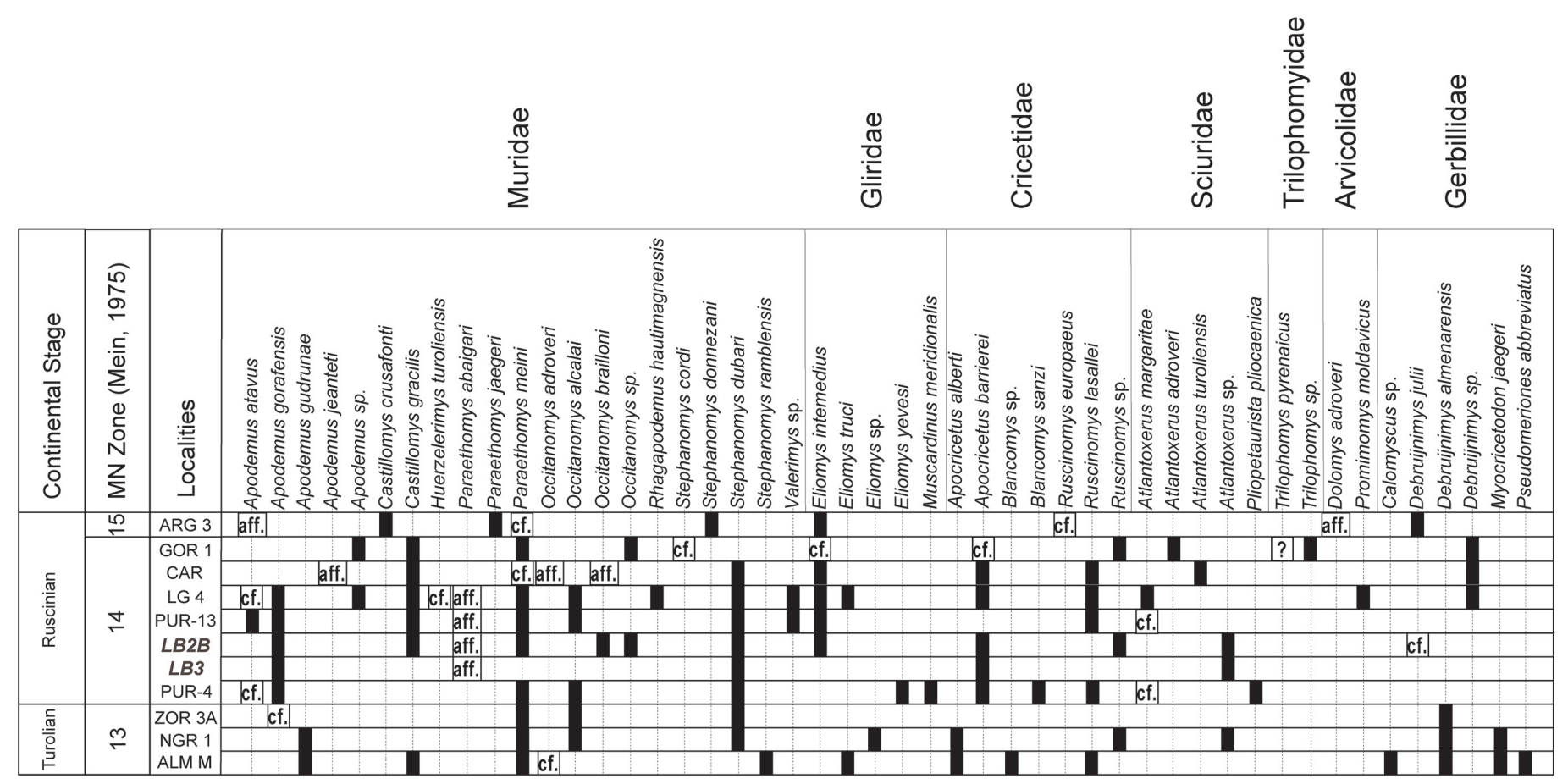

Fig. 4.- Distribution chart of the rodents studied in this paper and of related species of similar age. Abbreviations: ARG3, Asta Regia 3 (Castillo and Agustí, 1996); GOR 1, Gorafe 1 (Bruijn, 1974; Martín-Suárez and Mein, 1991; Agustí and Martín-Suárez, 1984); CAR, Caravaca (Freudenthal et al., 1998, Bruijn et al., 1975, Weerd 1976, Aguilar et al., 1991); LG 4, La Gloria 4 (Mein et al., 1990); PUR-13, Purcal 13 (García-Alix, 2006); LB3, La Bullana 3 and LB2B, La Bullana 2B (this paper); PUR-4, Purcal 4 (García-Alix et al., 2008c; Mansino et al., in press); ZOR3 A, Zorreras 3A (Martín-Suárez et al., 2000); NGR 1, Negratín 1 (Minwer-Barakat et al., 2009 and 2012); ALM M, Almenara M (Agustí and Galobart, 1986; Agustí et al., 2011). For making this figure the following synonymies have been taken in account: Apodemus dominans as A. atavus; Castillomys crusafonti gracilis as C. gracilis; Paraethomys anomalus as P. meini; Stephanomys medius as $S$. cordii; Cricetus barrierei as Apocricetus barrierei; Protatera almenarensis as Debruijnimys almenarensis; Protatera sp. as Debruijnimys sp.

and AL2-D (Mansino et al., 2013). The molars from the two latter localities are slightly larger, having usually higher longitudinal crests and are clearly higher crowned than the teeth from La Bullana 2B and La Bullana 3. For these reasons, we ascribe the material from the studied localities to $S$. dubari.

Family Gerbillidae Alston, 1876

Subfamily Taterillinae Chaline, Mein and Petter, 1977

Genus Debruijnimys Castillo and Agustí, 1996

Debruijnimys cf. julii Castillo and Agustí, 1996 (Fig. 5, 1)

Locality: LB2B.

Material: 1 M1 (LB2B-248).

\section{Description:}

M1: (2.78 x 2.03): The anterocone is sub-triangular, with a flat anterior face. An indentation on the anterior face of the anterocone subdivides this cusp into two lobes. There is a posterior spur on the lingual lobe of the anterocone, directed towards the protocone-paracone junction. The anterocone and the protocone are linked by a low longitudinal ridge. The protocone and paracone are equivalent in size, and separated from the hypocone-metacone complex by a deep valley. The posterior walls of the protocone and the paracone show low posterior spurs that connect, at medium level, to the hypocone and the metacone, respectively. The hypocone is larger than the metacone, and posteriorly displaced. There is a shallow furrow between hypocone and metacone. Roots are not preserved.

\section{Discussion:}

In the Iberian Peninsula several Late Miocene and Early Pliocene localities have yielded remains of Debruijnimys Castillo and Agustí, 1996 (see Agustí and Casanovas-Vilar, 2003 and Minwer-Barakat et al., 2009b). The record of Debruijnimys in Spain comprises two species: D. almenarensis (Agustí, 1990) from the Late Miocene (MN13) and D. julii Castillo and Agustí, 1996 from the middle Pliocene (MN15). Debruijnimys almenarensis is recorded in Salobreña, Almenara M, Zorreras 2B and 3A, and Negratín-1 (Agustí, 1990; Agustí, 1991; Martín-Suárez et al., 2000; Minwer-Barakat et al., 2009b; Agustí et al., 2011) and D. julii in Asta Regia-3 (Castillo and Agustí, 1996).

Other Spanish localities of Early Ruscinian age (MN14) with presence of the genus Debruijnimys are Alcoy, Caravaca, Gorafe 1, Botardo, Bacochas 1 and La Gloria 4 (Sesé, 1989; Agustí, 1991; Castillo and Agustí, 1996 and MinwerBarakat et al., 2009b) (Fig. 4). The scarcity of material in these localities led the authors to determine these specimens as Debruijnimys sp.; Agustí and Casanovas-Vilar (2003) considered that all these samples from the Ruscinian referred to Debruijnimys sp. were forms related to $D$. julii. 


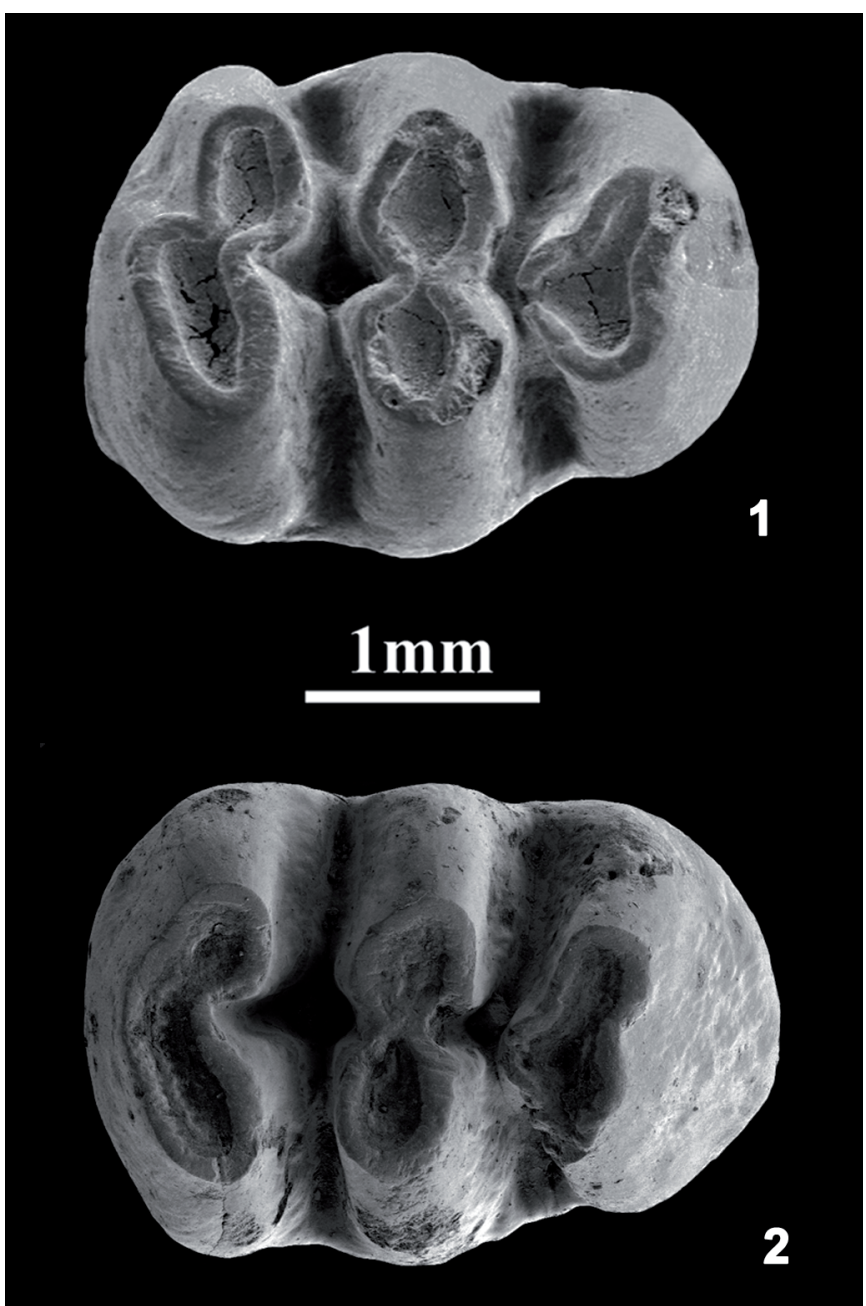

Fig. 5.- Debruijnimys cf. julii from La Bullana 2B (Cabriel Basin). 1, right M1, LB2B-248. Debruijnimys almenarensis from Almenara M, 2, right M1, MGUV-27742.

The phylogenetic relationship of the Spanish forms of $D e$ bruijnimys is not clear. Thus, the larger size and the presence of derived characters in D. almenarensis (MN13), like the very large anteroconid, led Agustí and Casanovas-Vilar (2003) to refuse an ancestor-descendant relationship between D. almenarensis and the Spanish material of Debruijnimys from the Early Ruscinian (MN14). According to these authors, the forms of Debruijnimys of Early Ruscinian age would be an intermediate step in a phylogenetic lineage comprising $D$. davidi from Lissafa (Morocco) (Late Turolian, MN13, 5.5 Ma) (Raynal et al., 1999) and D. julii from Asta Regia 3 (Late Ruscinian, MN15).

The upper molars of $D$. julii differ from those of $D$. almenarensis by several characters, like the presence of a weak indentation on the anterior face of the anterocone that creates two confluent lobes and the degree of separation between the protocone-paracone and hypocone-metacone pairs. While in $D$. almenarensis there is a wide valley, without posterior spurs (Fig. 5, 2), in D. julii there is a low connection between the posterior walls of the protocone and paracone and the anterior sides of the hypocone and metacone, respectively (Fig. 5, 1) (Castillo and Agustí, 1996, Plate 1, Fig. 4-5). Moreover, the shape of the M1, sub-rectangular in the M1 of D. almenarensis (Fig. 5, 2) and more rounded in D. julii (Fig. 5, 1) is another difference between both species.

Minwer-Barakat et al. (2009b) observed an increase in size from $D$. davidi from Lissasfa to $D$. julii from Asta Regia. The size of the material of the Early Ruscinian Spanish populations of Debruijnimys is similar to that of $D$. julii (Castillo and Agustí, 1996) and much larger than that of D. davidi from Lissasfa (Geraads, 1998). The M1 from La Bullana 2B is much larger than those of $D$. davidi from Lissasfa and very similar in size to those of $D$. almenarensis and $D$. julii (Agustí, 1990; Martín Suárez et al.; 2000; Minwer-Barakat et al. 2009b).

Moreover, the M1 from La Bullana 2B clearly differs from those of Lissasfa in the morphology of hypocone-metacone pair. While in Lissasfa the metacone is placed posteriorly with respect to the hypocone, in La Bullana $2 \mathrm{~B}$ the metacone is placed anteriorly. In the single M1 from La Bullana 2B, the metacone is placed in a more anterior position with respect to the hypocone than in $D$. almenarensis from its type locality, Almenara M (Fig. 5, 2), and similar to that of D. julii (Castillo and Agustí, 1996).

The morphology of the anterocone of the M1 from La Bullana $2 \mathrm{~B}$ is more similar to $D$. almenarensis and $D$. julii than to $D$. davidi. The presence of a weak indentation on the anterior face of the anterocone, that creates two confluent lobes, is present in $D$. julii and, in a lesser degree, also in D. almenarensis from Almenara M (Fig. 5, 2), and in Debruijnimys from La Bullana 2B, being absent in the M1 of $D$. davidi from Lissasfa. The absence of lower dentition and other elements of the upper dentition in La Bullana 2B do not allow going further in the comparison between the African and the Spanish forms of Debruijnimys of Late Miocene-Early Pliocene age.

Based on the size, the less elongated shape of this specimen, the presence of low posterior spurs connecting the protocone-hypocone and paracone-metacone pairs and the more accentuated asymmetry in the position of metacone and hypocone in the M1 of Debruijnimys from La Bullana 2B, we distinguish this tooth from $D$. almenarensis and assign it to a form related with $D$. julii.

Family Gliridae Muirhead, 1819

Subfamily Dryomyinae de Bruijn, 1967

Genus Eliomys Wagner, 1840

Eliomys intermedius Friant, 1953 (Fig. 6, 8-10)

Locality: LB2B.

Material: 4 m1-2 (LB2B-6, LB2B-176, LB2B-242, LB2B243), $1 \mathrm{~m} 3$ (LB2B-179), 1 P4 (LB2B-178), 1 M1-2 (LB2B241), 1 M3 (LB2B-177).

\section{Description:}

$m 1-2$ : (1.42 x $1.77 ; 1.51 \times-;-\times 1.50$; broken specimen): The anterolophid is connected to the protoconid in 1 out of 4 specimens. There is no anterotropid. There is a low connection between metalophid and metaconid. The centrolophid is 


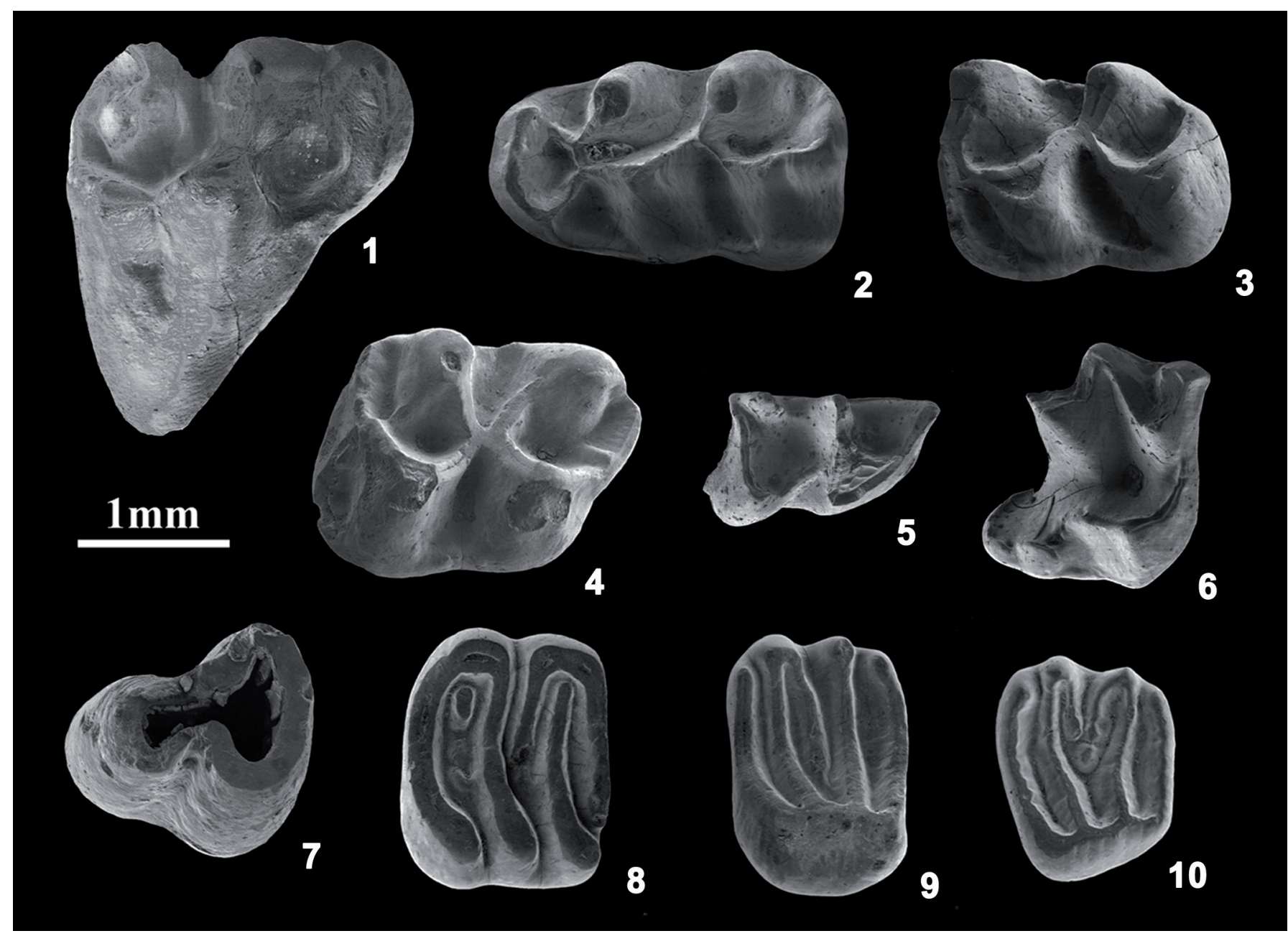

Fig. 6.- Rodents and insectivores from La Bullana 2B and La Bullana 3, Cabriel Basin, Spain. Atlantoxerus sp. from LB2B. 1, right D4, LB2B-244. Apocricetus barrierei from LB2B. 2, left m1, LB2B-141; 3, left m3, LB2B-232; 4, left M2, LB2B-220. Asoriculus cf. gibberodon from LB2B and LB3. 5, right m1, LB2B-245; 6, right M1, LB3-31. Ruscinomys sp. from LB2B. 7, right m3, LB2B-175. Eliomys intermedius from LB2B. 8, right m1-2, LB2B-176; 9, left M1-2, LB2B-241; 10, left M3, LB2B-177. Scale bar equals 1 mm.

long and not connected to the metalophid but in one specimen. There is no endolophid. The mesolophid is connected to entoconid. The posterotropids are well developed. Roots are not preserved.

$m 3$ : The only available tooth is broken anteriorly. The posterotropid is absent. The centrolophid is shorter than in the $\mathrm{m} 1-2$. There is no endolophid. The posterolophid is continuous. Roots are not preserved.

P4: (1.08 x 1.48): Subtriangular outline. There is no anteroloph, and the protoloph is discontinuous. The paracone and metacone are higher than the protocone. There is a welldeveloped precentroloph and a short postcentroloph. The endoloph is continuous. Roots are not preserved.

M1-2: (1.25 x 1.79): The anteroloph is separated from both protoloph and paracone by a deep valley. There is neither anterotrope nor posterotrope. Paracone and metacone are high and separated from each other. The protoloph and metaloph are continuous. In the only complete specimen the precentroloph is long, and the postcentroloph absent (Fig. 6, 8). The endoloph and posteroloph are connected and continuous. Roots are not preserved.
M3: (1.27 x 1.52): Trapezoidal outline, with the anterior part notably wider than the posterior side. The anteroloph is separated from protoloph, but closer to paracone than in M12. Both anterotrope and posterotrope are absent. The paracone and metacone are high and separated, and attached to a continuous protoloph and metaloph, respectively. Both centrolophs are present and well developed, being the postcentroloph longer and interrupted near its lingual end (Fig. 6, 9). The endoloph and posteroloph are connected and continuous. Roots are not preserved.

\section{Discussion:}

The specimens from La Bullana 2B are larger, more concave and have a more rounded outline than those of Eliomys truci Mein and Michaux 1970 and Eliomys yevesi Mansino, García-Alix, Ruiz-Sánchez and Montoya, 2014. Their size is similar to Eliomys intermedius Friant, 1953 from Sète and Orrios 3 (Adrover, 1986), PUR-13, TCH-3, TCH-1B and TCH-13 (García-Alix et al., 2008b) and Eliomys cf. intermedius from Arquillo 3, Villalba Alta (Adrover, 1986) and Mont Hélène (Aguilar et al., 1986). The presence of two centro- 
lophs, being the postcentroloph well-developed (Fig. 6, 9), in the single M3 from La Bullana 2B agree with the species Eliomys intermedius.

Family Sciuridae Fisher, 1817

Subfamily Pteromyinae Brandt, 1855

Genus Atlantoxerus Forsyth Major, 1893

Atlantoxerus sp. (Fig. 6, 1)

Localities: LB2B, LB3

Material: 1 D4 (LB2B-244), 1 m1-2 (LB3-47)

\section{Description:}

D4: (2.36 x -): Tooth broken posterolabially. Sub-triangular outline. The parastyle is connected to the anteroloph, and separated from the protoloph by a wide and deep valley. The protocone is well developed, very high and connected to the paracone by the protoloph. The metacone is partially broken, and connected to the metaconule by a narrow crest. Both cusps are very close to each other and connected basally to the posteroloph. The metaconule is separated from the hypocone and protocone by a deep valley. Roots are not preserved.

m1-2: Molar broken anteriorly. The posterolophid bears a small hypoconulid, and connects the entoconid to the hypoconid. Roots are not preserved.

\section{Discussion:}

Heteroxerus and Atlantoxerus differ mainly in size, but Atlantoxerus has also higher crowns and cusps, more rounded conules and wider crests (Cuenca-Bescós, 1988). The studied specimens are larger than those of Heteroxerus, Atlantoxerus cuencae Aguilar, Calvet and Michaux, 1995, A. martini Aguilar, 2002 and A. idubedensis Cuenca, 1988, They are clearly smaller than those of Atlantoxerus tadlae (Lavocat, 1961), slightly smaller than $A$. cf. margaritae from La Gloria-2 and Villalba Alta, and slightly larger than the same taxon from Aldehuela (Adrover et al., 1993). The D4 is shorter but wider than that of A. cf. margaritae from Purcal-4 (García-Alix et al., 2007). Atlantoxerus adroveri de Bruijn and Mein, 1968, from Concud 3 (Weerd, 1976), and A. rhodius De Bruijn, Dawson and Mein, 1970 are slightly smaller than our specimens. Due to the scarcity and bad preservation of the recovered specimens we cannot confirm whether the Atlantoxerus from La Bullana $2 \mathrm{~B}$ is a form related to A. margaritae or to A. adroveri, so we ascribe these molars to Atlantoxerus sp.

Sciuridae indet.?

Locality: LB2B.

Material: 1 m1,2 (LB2B-254).

\section{Description:}

m1-2: The molar is broken posterolingually. The protoconid is large, and connected to a well-developed anteroconulid. There is a weak anterior cingulid. The crest that connects the protoconid and the hypoconid is slightly swollen, forming a weak mesoconid. Roots are not preserved.

\section{Discussion:}

The specimen from La Bullana 2B certainly corresponds to a sciurid, but it is much smaller than the other remains of sciurids found in this locality ascribed to Atlantoxerus. The presence of an anterior cingulid is characteristic of some species of Heteroxerus, although a reduced cingulid may be present in some species of Atlantoxerus, like Atlantoxerus blacki (Cuenca-Bescós, 1988). Therefore, a more precise determination of this tooth is not possible.

Family Cricetidae Fischer, 1817

Subfamily Cricetinae Fischer, 1817

Genus Apocricetus Freudenthal, Mein and Martín-Suárez, 1998 Apocricetus barrierei (Mein and Michaux, 1970)

Localities: LB2B, LB3.

Material, descriptions and Measurements: in Ruiz-Sánchez et al., 2014.

\section{Discussion:}

The assemblages from La Bullana 2B and La Bullana 3 have an intermediate size between $A$. angustidens and $A$. alberti. The $\mathrm{m} 1$ from La Bullana $2 \mathrm{~B}$ have a crest-like anteroconid, with a weak subdivision, with two anterolophulids arising from a prelophid. In 2 out of 12 specimens there is a third crest pointing backwards from the middle of the anteroconid. The mesolophids are generally absent in $\mathrm{m} 1$ and $\mathrm{m} 2$. The $\mathrm{m} 3$ is generally longer than the $\mathrm{m} 2$, having a complete mesolophid in 3 out of 13 specimens. In the $\mathrm{m} 3$ from La Bullana 3 the mesolophid is absent.

In La Bullana 2B, the cingulum ridge on the base of the anterocone of M1 is absent (5) or weak (1). Of the seven M1, two have a complete anterior protolophule, one has a weakly developed crest and four have no crest at all. The posterior metalophule is very scarce in M1. 16 out of $20 \mathrm{M} 2$ from La Bullana 2B have an anterior protolophule, whereas the only complete M2 from La Bullana 3 lacks this ridge. 4 out of 17 M2 from La Bullana 2B and 1 out of 3 from La Bullana 3 have a hint of metalophule. In the M3 an anterior protolophule is always present, being complete in 9 out of 13 specimens from La Bullana 2B and in 1 out of 2 from La Bullana 3.

The size of the Apocricetus assemblages from La Bullana 2B and La Bullana 3 agrees with that of $A$. barrierei (Freudenthal et al., 1998; Ruiz-Sánchez et al., 2014).

The lower molars of $A$. barrierei from La Bullana $2 \mathrm{~B}$ and La Bullana 3 differ from those of $A$. aff. plinii and $A$. plinii in the weakly split anteroconid in $\mathrm{m} 1$, the more pronounced enlargement of $\mathrm{m} 3$ and the absence of mesolophids in most $\mathrm{m} 1-2$. The prelophid is present in some specimens of $A$. alberti, but is less developed than in A. barrierei (Mansino et al., 2014).

The M1-2 of A. barrierei from La Bullana 2B and La Bullana 3 differ from those of $A$. aff. plinii and $A$. plinii by the 
bifid anterolophule in the M1 and the absence of mesoloph in the M1-2. Some specimens of A. alberti and A. barrierei develop a weak cingulum ridge on the base of the anterocone of M1 (Mansino et al., 2014). This ridge is well-developed in A. angustidens.

The anterior protolophule of the upper molars is less developed in A. barrierei from La Bullana $2 \mathrm{~B}$ and La Bullana 3 than in $A$. aff. plinii, A. plinii and A. alberti, and higher than in $A$. angustidens. In addition, the presence of posterior metalophule, complete or hinted, in A. barrierei from La Bullana $2 \mathrm{~B}$ and La Bullana 3 differs from those of $A$. angustidens.

Therefore, on the basis of metric and morphological features, the material of the genus Apocricetus from La Bullana 2B and La Bullana 3 may be assigned to A. barrierei.

Subfamily Cricetodontinae Stehlin and Schaub, 1951 Genus Ruscinomys Depéret, 1890

Ruscinomys sp.

Locality: LB2B.

Material: 1 M3 (LB2B-175).

\section{Description:}

M3: (1.80 x 1.54): The dentine is completely lost. This molar has two lobes delimited by the sinus and mesosinus. The posterior lobe is smaller than the anterior one. Roots are not preserved.

\section{Discussion:}

Because of its general morphology and hypsodonty, we can ascribe the unique cricetodontine tooth from LB2B to the genus Ruscinomys, although a specific determination is not possible. The only available is an M3, an element which lacks most diagnostic characters. Adrover (1969) noted that the M3 of Ruscinomys lasallei Adrover, 1969, and R. schaubi Villalta and Crusafont Pairó, 1956, are less reduced than those of $R$. europaeus Déperet, 1890. The M3 from La Bullana 2B differs from the latter species by the presence of two well-developed lobes. However, distinguishing between $R$. lasallei and $R$. schaubi is difficult. The size of the M3 from La Bullana 2B is consistent with the lower measurements of $R$. lasallei and $R$. schaubi and even with smallest values of $R$. europaeus. For all these reasons, we ascribe the specimen from La Bullana 2B to Ruscinomys sp.

Order Soricomorpha Gregory, 1910

Family Soricidae Fischer von Waldheim, 1817

Subfamily Soricinae Fischer von Waldheim, 1817

Tribe Nectogalini Anderson, 1879

Genus Asoriculus Kretzoi, 1959

Asoriculus cf. gibberodon (Petényi, 1864) (Fig. 6, 5-6)

Localities: LB2B, LB3.

Material: 1 m1 (LB2B-245), 1 M1 (LB3-31).

\section{Description:}

m1: (L: 1.44; TRW: 0.77; TLW: 0.91): The talonid is wider than the trigonid. The hypolophid is well developed and does not reach the entoconid. There is a well-developed oblique crest, which connects the hypoconid with the trigonid. The metaconid is slightly higher than the paraconid. The depression of the trigonid is open and ' $\mathrm{V}$ ' shaped. The protoconid is broken. The lingual cingulid is low and narrow. The labial cingulid is reduced. Roots are not preserved.

M1: (LL: 1.57; AW: 1.68): The metaloph does not reach the hypocone. There is a well-developed hypoconal flange and a pronounced posterior emargination. The basal connection between the hypocone and posteroloph agrees with the morphotype B described by Reumer (1984). The preprotocrista is in contact with the paracone. The parastyle is short. The paracrista is the shortest crest in the ectoloph. The paramesocrista is longer than the postmesocrista. The metastyle is broken. The metacone is higher than the paracone. The ectoloph is asymmetric. Roots are not preserved.

\section{Discussion:}

Asoriculus gibberodon is the smallest species of the genus, and very common in the Pliocene of Europe (Minwer-Barakat et al., 2010; Furió and Angelone, 2010). The presence of a large protoconid and a complete basal cingulid in lower molars are typical features of A. gibberodon (Furió, 2007). The hypocone attached to the posteroloph in the M1 agree with the morphotype B of Reumer (1984). The size of the $\mathrm{m} 1$ is consistent with the minimum values of the molars from Villany 3, Csarnota 2, Ostrazmos 1 and 9 (Reumer, 1984), Varshets (Popov, 2003), Fuente Nueva 3 (Furió, 2007), TCH1 and TCH-3 (Minwer-Barakat et al., 2010) and Capo Mannu D1 (Furio and Angelone, 2010). The size of the M1 matches the largest values of the specimens from the mentioned localities. This great biometrical variability is usual in $A$. gibberodon (Reumer, 1984; Minwer-Barakat et al., 2010).

\section{Discussion}

\subsection{Biostratigraphy}

Figure 4 contains information on the stratigraphical distribution of the rodent faunas described in La Bullana 2B and La Bullana 3, besides other of Spanish localities from MN13 to MN15. The locality of La Bullana 2B contains Apodemus gorafensis, Castillomys gracilis, Paraethomys aff. abaigari, Paraethomys meini, Occitanomys brailloni, Occitanomys sp., Stephanomys dubari, Eliomys intermedius, Apocricetus barrierei, Ruscinomys sp., Atlantoxerus sp., Sciuridae indet., Debruijnimys cf. julii and Asoriculus cf. gibberodon. On the other hand, the locality La Bullana 3 contains Apodemus gorafensis, Paraethomys aff. abaigari, Stephanomys dubari, Apocricetus barrierei, Atlantoxerus sp., and Asoriculus cf. gibberodon. The coexistence of Apodemus gorafensis, Paraethomys meini, Castillomys gracilis and Stephanomys dubari 
is considered typical of the latest Turolian-earliest Ruscinian (García-Alix et al., 2008a). The size and morphology of Stephanomys present in La Bullana 2B and La Bullana 3, with some specimens close to $S$. cordii, are similar to the molars from the lower Ruscinian (MN14) sites of PUR-4, PUR7 and PUR-13 (García-Alix et al., 2008a).

Other species of biostratigraphic relevance in La Bullana 2B are Occitanomys brailloni and Paraethomys aff. abaigari. Occitanomys brailloni appears in MN14, extending its range to MN16 (Weerd, 1979; Ruiz Bustos et al., 1984; Castillo, 1990; Minwer-Barakat, 2005). Paraethomys aff. abaigari is found together with the smaller $P$. meini in some localities of the MN14, like PUR-13, CLC-5A, Celadas-14, Celadas-5, Celadas-5A, La Gloria 4 and Celadas 9 (García-Alix et al., 2008c). In older localities, closer to the MN13-MN14 boundary like PUR-4, P. meini shows a wide size range, which may indicate that the lineage of $P$. abaigari is already present in those assemblages, and in Peralejos E two specimens are close to $P$. aff. abaigari (García-Alix et al., 2008a).

Regarding the cricetids, the presence of Apocricetus barrierei in La Bullana 2B and La Bullana 3 clearly indicates a lower Ruscinian age for these localities (Freudenthal et al., 1998; García-Alix et al., 2008b).

In La Bullana 2B, glirids are represented by Eliomys intermedius. This species appears in MN14 (Sesé, 2006), being La Gloria 4 in the Teruel basin (Mein et al., 1990), and PUR-13 in the Granada Basin (García-Alix et al., 2008b), the oldest records of this taxon. The faunal assemblage of La Bullana 2B indicates a similar age for the three localities (see Fig. 4).

Debruijnimys julii was described in the middle Pliocene (MN15) locality of Asta Regia (Castillo and Agustí, 1996), where Stephanomys donnezani, Paraethomys jaegeri and Paraethomys cf. meini are also present. This assemblage is clearly younger than that from LB2B.

Debruijnimys sp. has been cited in the lower Ruscinian sites of Gorafe 1, La Gloria 4, Alcoy 4B and Caravaca (Minwer-Barakat et al., 2009b). Gorafe 1, from the latest MN14 is included by Minwer-Barakat et al. (2012) in the Trilophomys Assemblage Zone of the Guadix basin, characterized by the association of Apocricetus barrierei, Stephanomys cordii, Castillomys gracilis, Apodemus gorafensis, Paraethomys meini and Trilophomys.

With respect to La Gloria 4, this locality belongs to the Promimomys and Paraethomys Assemblage Zone of the Teruel basin, within the MN14, where two species of Paraethomys, P. meini and P. abaigari, coexist (Mein et al., 1990). The presence of Stephanomys dubari, two Paraethomys species and Apocricetus barrierei suggest a similar age for La Gloria 4 and La Bullana 2B and La Bullana 3 (Fig. 4). In Caravaca, the presence of S. dubari, Apocricetus barrierei, Castillomys gracilis and a big-sized Apodemus indicate a similar age to that of La Bullana 2B and La Bullana 3 (Freudenthal et al., 1998; Bruijn et al., 1975; Weerd, 1976; Aguilar et al., 1991).

According to these observations, Debruijnimys sp. from Gorafe 1 and Alcoy 4B are younger than the form present in
La Bullana 2B, and Debruijnimys sp. from Caravaca and La Gloria 4 may be of a similar age. The sites where D. almenarensis is present, Negratín-1 and Almenara $\mathrm{M}$, correspond to the Late Turolian and are clearly older than La Bullana 2B and La Bullana 3.

\subsection{Paleomagnetism}

A preliminary paleomagnetic study was carried out in the localities La Bullana 2B and La Bullana 3. We collected five samples to produce a preliminary paleomagnetic study around La Bullana sites, which are stratigraphically above the classical site of Venta del Moro, dated at 6.23 Ma (Gibert et al., 2013). The samples from La Bullana 3 show normal polarity, like the two lower samples from La Bullana 2B, while the two upper samples from this locality show reverse or ambiguous polarities, indicating a normal-reverse polarity sequence (Fig. 2). The presence of a basal normal zone, the differences with Venta del Moro fauna and the similarities with sites located in the latest Miocene or earliest Pliocene suggest that the identified normal zone should be correlated with chron $\mathrm{C} 3 \mathrm{n} .4 \mathrm{n}$ in the earliest Pliocene, dated between 5.235 Ma and 4.997 Ma (Lourens et al., 2005). Therefore, the fauna of La Bullana 3 can be constrained to the age of this chron and the site La Bullana 2B, placed a few meters above its upper boundary, should be constrained between the age of this boundary (4.997 Ma) and the next magnetic reversal at 4.896 Ma.

\subsection{Paleoecology}

The analysis of micromammal assemblages has been widely used as a paleoclimatic indicator (Weerd, 1976; Daams et al., 1988; Casanovas-Vilar and Agustí, 2007; García-Alix et al., 2008; Furió et al., 2011).

Some authors have proposed a minimum sample size of at least 100 specimens when dealing with fossil assemblages (Daams et al., 1999; García-Alix et al., 2008d), while others used a minimum of 50 specimens (Casanovas-Vilar and Agustí, 2007), arguing that in most cases larger samples only add one or two species to the assemblage, with an abundance of less than $1 \%$. According to this, the sample from La Bullana 3 is too scarce to carry out any paleoecologic inference, having yielded just 32 specimens. For this reason we only present here the data from La Bullana 2B.

To interpret the paleoecologic requirements of each taxon found in La Bullana 2B, we have used mainly the climatic and habitat preferences proposed by García Alix et al. (2008d). According to that work, a number of taxa are considered as warm weather indicators (Apodemus gorafensis, Paraethomys meini, Apocricetus, Atlantoxerus and Asoriculus gibberodon), whereas Ruscinomys, of which a single element has been found, indicates cold conditions. Regarding the humidity, the presence of P. meini, Ruscinomys and Atlantoxerus has been associated with dry conditions, while $A$. 


\begin{tabular}{|c|c|c|c|c|c|c|c|}
\hline & $\mathbf{N}$ & DE & N/DE & $\mathbf{R A}$ & Temperature & Humidity & Habitat \\
\hline Apodemus gorafensis & 26 & 12 & 2.17 & 10.43 & W & $\mathrm{H}$ & E \\
\hline Castillomys gracilis & 17 & 12 & 1.42 & 6.81 & $\mathrm{E}$ & $\mathrm{E}$ & $\mathrm{E}$ \\
\hline Occitanomys brailloni & 17 & 12 & 1.42 & 6.81 & $\mathrm{U}$ & $\mathrm{U}$ & $\mathrm{U}$ \\
\hline Occitanomys sp. & 1 & 12 & 0.08 & 0.40 & $\mathrm{U}$ & $\mathrm{U}$ & $\mathrm{U}$ \\
\hline Paraethomys aff. abaigari & 36 & 12 & 3.00 & 14.43 & $\mathrm{U}$ & $\mathrm{U}$ & $\mathrm{U}$ \\
\hline Paraethomys meini & 27 & 12 & 2.25 & 10.82 & W & $\mathrm{D}$ & $\mathrm{E}$ \\
\hline Stephanomys dubari & 25 & 12 & 2.08 & 10.02 & $\mathrm{E}$ & $\mathrm{E}$ & $\mathrm{E}$ \\
\hline Apocricetus barrierei & 89 & 12 & 7.42 & 35.68 & $\mathrm{~W}$ & E & $\mathrm{O}$ \\
\hline Ruscinomys sp. & 1 & 12 & 0.08 & 0.40 & $\mathrm{C}$ & $\mathrm{D}$ & $\mathrm{O}$ \\
\hline Debruijnimys cf. julii & 1 & 12 & 0.63 & 3.01 & $\mathrm{U}$ & $\mathrm{D}$ & $\mathrm{U}$ \\
\hline Eliomys intermedius & 10 & 16 & 0.08 & 0.40 & $\mathrm{E}$ & E & E \\
\hline Atlantoxerus sp. & 1 & 16 & 0.06 & 0.30 & W & $\mathrm{D}$ & $\mathrm{O}$ \\
\hline Sciuridae indet. & 1 & 16 & 0.05 & 0.24 & $\mathrm{U}$ & $\mathrm{U}$ & $\mathrm{U}$ \\
\hline Asoriculus cf. gibberodon & 1 & 20 & 0.05 & 0.24 & W & $\mathrm{H}$ & $\mathrm{F}$ \\
\hline TOTALS & & & & & $\begin{array}{c}\text { Warm: } 57.87 \% \\
\text { Cold: } 0.40 \% \\
\text { Eurytopic: } 19.84 \% \\
\text { Unknown: } 21.89 \%\end{array}$ & $\begin{array}{c}\text { Humid: } 10.66 \% \\
\text { Dry: } 11.93 \% \\
\text { Eurytopic: } 55.52 \% \\
\text { Unknown: } 21.89 \%\end{array}$ & $\begin{array}{c}\text { Open: } 36.78 \% \\
\text { Forested: } 0.25 \% \\
\text { Eurytopic: } 41.09 \% \\
\text { Unknown: } 21.88 \%\end{array}$ \\
\hline
\end{tabular}

Table 6.- Paleoecological affinities of the taxa from the studied localities. The relative abundance (RA) of each taxon is calculated following Martín-Suárez (1988), dividing the number of specimens $(\mathrm{N})$ by the number of diagnostic elements (DE) of each group. Abbreviations: C, cold; DE, diagnostic elements; D, dry; E, eurytopic; F, forested; H, humid; N, number of specimens; $\mathbf{O}$, open; RA, relative abundance; $\mathbf{U}$, unknown; W, warm.

gorafensis, Eliomys intermedius and A. gibberodon would indicate a wet environment. The presence of Apocricetus, Ruscinomys and Atlantoxerus indicates open habitats, whereas Eliomys intermedius and Asoriculus gibberodon would suggest the presence of forested zones in the area (García-Alix et al., 2008d). However, Freudenthal et al., (2014) point out that the genus Eliomys cannot be considered a humid environment indicator based on the ecological affinities of extant E. quercinus, which is a habitat generalist, and the distribution of E. munbyanus and E. melanurus, restricted to semidesert environments. Therefore, we consider E. intermedius, probable ancestor of E. quercinus (García-Alix et al., 2008b), and eurytopic taxon regarding both habitat and humidity. The presence of the gerbilid Debruijnimys suggests a dry and arid environment (Minwer-Barakat et al., 2009b), and the affinities of $P$. aff. abaigari, Occitanomys brailloni and Occitanomys sp. are unknown (García-Alix et al., 2008d).

The proportions of the taxa within each ecological category are shown in table 6 . Regarding the humidity, most of the taxa recorded in La Bullana 2B are eurytopic $(55.52 \%)$ or with unknown affinities ( $P$. aff. abaigari and Occitanomys brailloni and sp. $21.89 \%)$. Because of that, the relative proportion of humid $(10.66 \%)$ and dry (11.93\%) environment indicators does not seem very representative. However, most of the taxa studied in this work are considered as typical to warm environments (57.87\%), and the abundance of Apocricetus together with Ruscinomys and Atlantoxerus and the presence of Debruijnimys suggest an open environment (36.78\% of the assemblage). Therefore, we consider that the faunas from La Bullana 2B indicate warm conditions and probably an open environment with some patches of vegetation.

\subsection{Considerations on the "gerbil event" in Europe according} to the presence of Debruijnimys in La Bullana $2 B$

The Messinian Salinity Crisis (MSC) is the main event in the evolution of the Mediterranean during the Neogene. The beginning of the MSC took place about 5.96 Ma ago, with the closure of the Betic and Rifian seaways, which connected the Atlantic and Mediterranean domains. The Mediterranean was reflooded at the base of the Pliocene after the opening of a new seaway, the Gibraltar strait (Hsü et al., 1973). The effects of this event on the faunal exchanges between Africa and Europe during this time interval have been widely discussed in the literature, and several authors have accepted the creation of new migration routes for terrestrial organisms (Brandy and Jaeger, 1980; Agustí and Casanovas-Vilar, 2003; Aguirre, 2003; Made et al., 2006; Agustí et al., 2006; Minwer-Barakat et al., 2009b; Gibert et al., 2013, among others).

One of the taxa of African origin that colonised the Iberian Peninsula during the MSC is the gerbil Debruijnimys. Until now, only two species of this genus have been recorded in Europe, D. almenarensis, identified in some MN13 localities, and $D$. julii, only known from the type locality, Asta Regia (MN15).

The origin of $D$. almenarensis and $D$. julii has been discussed in several papers (Castillo and Agustí, 1996; Agustí and Casanovas-Vilar, 2003; Minwer-Barakat et al., 2009b), which has important paleobiogeographic implications. While D. almenarensis (MN13) has a clear African origin, related to the MSC Event, the origin of D. julii (MN15) is more difficult to establish. Thus, the dispersion processes which explain the presence of gerbils in Western Europe have proven to be 
very complicated. According to Agustí and Casanovas-Vilar (2003), there are, at least, two different waves of gerbil colonisation from northern Africa recorded in the Iberian basins. The first wave, of Late Turolian age (Late Miocene), involved D. almenarensis, whereas the second one corresponds to the representatives of Debruijnimys (Debruijnimys sp.) found in the Lower Pliocene (lower Ruscinian, MN14) localities of Alcoy, Gorafe, Caravaca and La Gloria 4. The presence of $A$. barrierei in Botardo, Alcoy 4B, Caravaca, La Gloria 4 (Freudenthal et al., 1998) and La Bullana 2B, confirm an Early Pliocene age (early Ruscinian, MN14) for these localities. La Bullana 2B is older than Alcoy 4B, probably slightly older than La Gloria 4 and similar in age to Caravaca and Botardo.

If $D$. julii is not the direct descendant of $D$. almenarensis, the presence of $D$. julii in the MN15 implies, necessarily, a second migration event from Africa to Europe in the span interval between MN13 and MN15 (Agustí and CasanovasVilar, 2003). Thus, according to Agustí and Casanovas-Vilar (2003), Debruijnimys sp. from the lower Ruscinian localities of Alcoy, Gorafe, Caravaca and La Gloria 4 (MN14) would be the descendant of $D$. davidi, and the ancestor of D. julii, known from the Late Ruscinian (MN15) site of Asta Regia 3.

However, there is a great similarity between $D$. almenarensis and the subsequent forms of Debruijnimys (see Fig. 5), and a direct ancestor-descendant relationship cannot be discarded. Still, if the presence of $D$. julii in MN14 is confirmed, it would expand the range of this taxon, until now recorded only in MN15. This would make the phylogeny of Debruijnimys even more complex, since the relationship between Debruijnimys sp. from MN14 and D. julii is not clear, and they may even be the same species. Another option would be a process of cladogenetic speciation along the Early Pliocene, resulting in two different lineages of Debruijnimys, and unnamed species and $D$. julii, but the relationship between this latter species and the forms present in MN14 is not clear, and they may be indeed the same taxon.

Nevertheless, any hypothesis on the phylogenetic relationships of Debruijnimys is difficult to test because of the scarce material of Debruijnimys sp. from the early Pliocene of the Iberian Peninsula. Only Alcoy 4B yielded a rich sample, but nowadays it is a lost locality. Therefore, until new material from Ruscinian sites becomes available, little more can be said in this regard.

The new data from La Bullana 2B contribute to improve the knowledge on the status of this lineage of African rodents in the Iberian Peninsula after the colonisation processes during the Messinian Salinity Crisis, but open new questions around the evolution of this group, too.

\section{Conclusions}

The faunal list of La Bullana 3 comprises Apodemus gorafensis, Paraethomys aff. abaigari, Stephanomys dubari, Apocricetus barrierei, Sciuridae indet. and Asoriculus cf. gibberodon. In addition to these taxa, La Bullana 2B has yielded remains of Castillomys gracilis, Occitanomys brailloni, Occitanomys sp., Paraethomys meini, Ruscinomys sp., Eliomys intermedius, Debruijnimys cf. julii and Atlantoxerus sp. Based on these faunal assemblages, we propose a lower Ruscinian age (MN14) for both localities.

The preliminary paleomagnetic analysis indicates an earliest Pliocene age for La Bullana 3 and La Bullana 2B. The age of La Bullana 3 lies probably within the C $3 n$. $4 n$ chron, dated between 5.235 Ma and 4.997 Ma. The age of La Bullana 2B should be constrained between the top of this chron (4.997 $\mathrm{Ma}$ ) and the next magnetic reversal at $4.896 \mathrm{Ma}$.

The presence of Eliomys intermedius in La Bullana 2B constitutes one of the oldest records of this taxon, probably equivalent to la Gloria 4 and PUR-13. The presence in La Bullana 2B of Apodemus gorafensis, Paraethomys meini, Apocricetus barrierei, Atlantoxerus and Asoriculus cf. gibberodon suggest warm conditions, and the relative abundance of Apocricetus, Ruscinomys and Atlantoxerus is consistent with an open environment.

The Early Ruscinian locality of LB2B constitutes the first record of a form related to Debruijnimys julii in MN14. However, the scarcity of the available material of Debruijnimys from Early Pliocene sites prevents any proper analysis, and its phylogenetic relationships remain controversial.

\section{Acknowledgments}

The campaigns of prospection and excavation in the area of Venta del Moro have been funded by the Conselleria de Cultura y Esports of the Valencian government since 1995. We thank the efficient work of the technicians of the SCSIE of the UV, P. Gómez, E. Navarro and A.J. Ibáñez. This investigation was carried out thanks to the Prometeo Project of the Secretariat for Higher Education, Science, Technology and Innovation from Ecuador. We thank Dr. Jordi Agustí for his comments. We thank the Paleomagnetic Laboratory CCiTUB-ICTJA CSIC where the paleomagnetic measurements were conducted and the Ramon y Cajal program of the Spanish Goverment for its help. This investigation has been funded through the project GV06/304 of the Conselleria d'Empresa, Universitat i Ciència "Estudio paleoambiental del tránsito Mioceno-Plioceno en facies continentales en la Comunidad Valenciana (Cuencas del Cabriel y de Alcoy)". This investigation was supported by projects CGL2011-25754 and CGL2011-28681 of the Spanish Ministry of Economy and Competitiveness.

\section{References}

Adrover, R. (1969): Los micromamíferos del Plioceno inferior de los lignitos de Alcoy. I. Ruscinomys. Boletín de la Real Sociedad Española de Historia Natural (Sección Geológica) 67, 245-272.

Adrover, R. (1986): Nuevas faunas de roedores en el Mio-Plioceno continental de la región de Teruel (España). Interés bioestratigráfico y paleoecológico. $\mathrm{PhD}$. Thesis, Instituto de Estudios Turolenses, $423 \mathrm{p}$.

Adrover, R., Mein, P., Moissenet, E. (1988): Contribución al conocimiento de la fauna de roedores del Plioceno de la región de Teruel. 
Teruel 79 (1), 89-151.

Adrover, R., Mein, P., Moissenet, E. (1993): Roedores de la transición Mio-Plioceno de la región de Teruel. Paleontologia i Evolució 26-27, 47-84.

Aguilar, J.P, Calvet, M., Michaux, J. (1986): Description des rongeurs pliocènes de la faune du Mont-Hélène (Pyrénées-Orientales, France), nouveau jalon entre les faunes de Perpignan (Serrat-Den-Vacquer) et de Sète. Paleovertebrata 16 (3), 127-144.

Aguilar, J. P., Michaux, J., Bachelet, B., Calvet, M., Faillat, J. P. (1991): Les nouvelles faunes de rongeurs proches de la limite Mio-Pliocene en Rousillon. Implications biostratigraphiques et biogeographiques. Paleovertebrata 20, 147-174.

Aguirre, E. (2003): Messiniense: compleja y grave crisis ecológica. Estudios Geológicos 59, 205-212.

Agustí, J. (1990): The Miocene rodent succession in Eastern Spain: a zoogeographical appraisal. In: E. H. Lindsay, V. Fahlbusch, \& P. Mein (eds), European Neogene Mammal Chronology. Plenum Press, New York, pp. 375-404

Agustí, J. (1991): Gerbilidés fossiles d'Europe occidentale. In: Le Berre, M. \& Guelte, L. (eds.), Le Rongeur et l'Espace, pp. 177-182.

Agustí, J., Galobart, A. (1986): La sucesión de micromamíferos en el complejo cárstico de Casablanca (Almenara, Castellón): problemática biogeográfica. Paleontologia y Evolució 20, 57-62

Agustí, J., Casanovas-Vilar, I. (2003): Neogene gerbils from Europe. Deinsea 10, 13-21.

Agustí, J., Martín-Suárez, E. (1984): El Plioceno continental de la depresión Guadix-Baza (Prov. Granada) y su fauna de micromamíferos. Nota preliminar. Acta Geologica Hispanica 19 (4), 277-281.

Agustí, J., Oms, O., Furió, M., Pérez-Vila, M. J., Roca, E. (2006): The Messinian terrestrial record in the Pyrenees: The case of Can Vilella (Cerdanya Basin). Palaeogeography, Palaeoclimatology, Palaeoecology 238, 179-189. doi:10.1016/j.palaeo.2006.03.024

Agustí, J., Santos-Cubedo, A., Furió, M., De Marfá, R., Blain, H. A., Oms, O., Sevilla, P. (2011): The late Neogene-early Quaternary small vertebrate succession from the Almenara-Casablanca karst complex (Castellón, Eastern Spain): Chronologic and paleoclimatic context. Quaternary International 243, 183-191. doi: 10.1016/j. quaint.2010.11.016

Benavent, J. V., Gascó, F., Ruiz-Sánchez, F. J., Montoya, P. (2008): Un Nuevo yacimiento con micromamíferos en el Mioceno Superior del área de Venta del Moro (Cuenca del Cabriel, Valencia). Stvdia Geologica Salmanticensia 8, 95-105.

Brandy, L. D., Jaeger, J.J. (1980): Les échanges de faunes terrestres entre l'Europe et l'Afrique nord-occidentale au Messinien. Comptesrendus de l'Académie des Sciences de Paris 291, 465-468.

Bruijn, H. de (1974): The Ruscinian rodent succession in Southern Spain and its implications for the bioestratigraphic correlation of Europe and North Africa. Senckerbergiana lethaea 55, 435-445.

Bruijn, H. de, Dawson, M. R., Mein, P. (1970): Upper Pliocene Rodentia, Lagomorpha and Insectivora (Mammalia) from the Isle of Rodhes (Greece). I, II y III. Proceedings Koninklijke Nederlandse Akademie van Wetenschappen 73, 536-584.

Bruijn, H. de, Mein, P., Montenat, C., Weerd, A. van de (1975): Corrélations entre les gisements de rongeurs et les formations marines du Miocéne terminal d'Espagne méridional I (Provinces d'Alicante et de Murcia). Proceedings Koninklijke Akademie van Wetenschappen 78, 314-338.

Casanovas-Vilar, I., Agustí, J. (2007): Ecogeographical stability and climate forcing in the Late Miocene (Vallesian) rodent record of Spain. Palaeogeography, Palaeoclimatology, Palaeoecology 248, 169-189. DOI:10.1016/j.palaeo.2006.12.002

Castillo, C. (1990): Paleocomunidades de Micromamíferos de los Yacimientos kársticos del Neógeno Superior de Andalucía Oriental. PhD. Thesis, Universidad de Granada, 225 p.
Castillo, C., Agustí, J., (1996): Early Pliocene rodents (Mammalia) from Asta Regia (Jerez basin, Southwestern Spain). Proceedings of the Koninklijke Nederlandse Akademie van Wetenschappen 991, 25-43.

Cuenca-Bescós, G. (1988): Revisión de los Sciuridos del Aragoniense y del Rambliense en la fosa de Calatayud-Montalbán. Scripta Geologica 87, 1-116.

Daams, R. (1981): The dental pattern of the Dormice Dryomys, Myomimus, Microdyromys and Peridyromys. Utrech Micropaleontological Bulletins special publication 3, 1-115.

Daams, R., Freudenthal, M., van der Meulen, A. J. (1988): Ecostratigraphy of micromammal faunas from the Neogene of Spain. Scripta Geologica, Special Issue 1, 286-302.

Daams, R., van der Meulen, A. J., Peláez-Campomanes, P., Alvarez Sierra, M.A. (1999): Trends in rodent assemblages from the Aragonian (early-middle Miocene) of the Calatayud-Daroca Basin, Aragón, Spain. In: Agustí, J., Rook, L., Andrews, P. (eds.), Hominoid evolution and climatic change in Europe. The evolution of Terrestrial Ecosystems in Europe. Cambridge University Press, Cambridge, U. K., vol. 1, pp. 127-139.

Freudenthal, M. (2004): Gliridae (Rodentia, Mammalia) from the Eocene and Oligocene of the Sierra Palomera (Teruel, Spain). Treballs del Museu de Geologia de Barcelona 12, 97-173.

Freudenthal, M., Mein, P., Martín-Suárez, E. (1998): Revision of Late Miocene and Pliocene Cricetinae (Rodentia, Mammalia) from Spain and France. Treballs del Museu de Geologia de Barcelona 7, 11-93.

Freudenthal, M., García-Alix, A., Rios, M., Ruiz-Sánchez, F. J., MartínSuárez, E., Delgado Huertas, A., 2014: Review of paleo-humidity parameters in fossil rodents (Mammalia): Isotopic vs. tooth morphology approach. Palaeogeography, Palaeoclimatology, Palaeoecology 395, 122-130. http://dx.doi.org/10.1016/j.palaeo.2013.12.023

Furió, M. (2007): Los insectívoros (Soricomorpha, Erinaceomorpha, Mammalia) del Neógeno superior del Levante Ibérico. PhD. Thesis, Universitat Autònoma de Barcelona, 341 p.

Furió, M., Angelone, C., (2010): Insectivores (Erinaceidae, Soricidae, Talpidae; Mammalia) from the Pliocene of Capo Mannu D1 (Mandriola, central-western Sardinia, Italy). Neues Jahrbuch fur Geologie und Palaontologie Abhandlungen 258, 229-242.

Furió, M., Casanovas-Vilar, I., van den Hoek Ostende, L. (2011): Predictable structure of Miocene insectivore (Lipotyphla) faunas in Western Europe along a latitudinal gradient. Palaeogeography, $\mathrm{Pa}$ laeoclimatology, Palaeoecology 304 (3-4), 219-229. doi:10.1016/j. palaeo.2010.01.039

García-Alix, A. (2006): Bioestratigrafía de los depósitos continentales de la transición Mio-Plioceno de la cuenca de Granada. PhD. Thesis, Universidad de Granada, 429 p.

García-Alix, A., Minwer-Barakat, R., Martín-Suárez, E., Freudenthal, M. (2007): New data on Mio-Pliocene Sciuridae (Rodentia, Mammalia) from southern Spain. Comptes Rendus Palevol 6, 269-279. doi:10.1016/j.crpv.2007.02.001.

García-Alix, A., Minwer-Barakat, R., Martín-Suárez, E., Freudenthal, M. (2008a): Muridae (Rodentia, Mammalia) from the Mio-Pliocene boundary in the Granada basin (southern Spain). Biostratrigraphic and phylogenetic implications. Neues Jahrbuch für Geologie und Paläontologie Abhandlungen 248, 183-215. doi: 10.1127/00777749/2008/0248-0183.

García-Alix, A., Minwer-Barakat, R., Martín-Suárez, E., Freudenthal, M. (2008b): Cricetidae and Gliridae (Rodentia, Mammalia) from the Miocene and Pliocene of southern Spain. Scripta Geologica 136, 1-37.

García-Alix, A., Minwer-Barakat, R., Martín, J. M., Martín Suárez, E. \& Freudenthal, M., (2008c): Biostratigraphy and sedimentary evolution of late Miocene and Pliocene continental deposits of the Granada Basin (southern Spain). Lethaia 41 (4): 431-446. doi: 10.1111/j.15023931.2008.00097.x

García-Alix, A. Minwer-Barakat, R., Martín-Suárez, E., Freudenthal, 
M., Martín, J. M. (2008d): Late Miocene-Early Pliocene climatic evolution of the Granada Basin (southern Spain) deduced from the paleoecology of the micromammal associations. Palaeogeography, Palaeoclimatology, Palaeoecology 265, 214-225. doi: 10.1016/j.palaeo.2008.04.005

Geraads, D. (1998): Rongeurs du Mio-Pliocène de Lissasfa (Casablanca, Maroc). Geobios 31, 229-245.

Gibert, L., Scott, G.R., Montoya, P., Ruiz-Sánchez, F. J., Morales, J., Luque, L., Abella, J., Lería. M. (2013): Evidence for an African-Iberian mammal dispersal during the pre-evaporitic Messinian. Geology 41, 691-694. doi: 10.1130/G34164.1

Hordijk, K., de Bruijn, H. (2009): The succession of rodent faunas from the Mio/Pliocene lacustrine deposits of the Florina-Ptolemais-Servia Basin (Greece). Hellenic Journal of Geosciences 44, 21-103.

Hsü, K. J., Montadert, L., Bernoulli, D., Cita, M. B., Erickson, A., Garrison, R. E., Kidd, R. B, Mèlierés, F., Müller, C., Wright, R. (1973): History of the Mediterranean salinity crisis. Nature 267, 399-403.

Lacomba, J. I., Morales, J., Robles, F., Santisteban, C., Alberdi, M. T. (1986): Sedimentología y paleontología del yacimiento finimioceno de La Portera (Valencia). Estudios Geológicos 42, 167-180.

Lourens, L., Hilgen, F., Shackleton, N.J., Laskar, J., Wilson, J. (2005): Chapter 21- The Neogene. In: Gradstein, F.M., Ogg, J.G., Smith, A.G. (Eds.), A Geologic Time Scale 2004. Cambridge University Press, Cambridge, U.K., pp. 409-430.

Made, J. van der, Morales, J., Montoya, P. (2006): Late Miocene turnover in the Spanish mammal record in relation to palaeoclimate and the Messinian Salinity Crisis. Palaeogeography, Palaeoclimatology, Palaeoecology 238, 228-246. http://dx.doi.org/10.1016/j.palaeo.2006.03.030

Mansino, S., Montoya, P., Luque, L., Ruiz-Sánchez, F. J., Benavent, J. V. (2009): La Bullana 2B: faunas de micromamíferos del Plioceno en el área de Venta del Moro (Valencia, España). Resúmenes XXV Jornadas de la Sociedad Española de Paleontología 1, 204-206.

Mansino, S., Fierro, I., Ruiz-Sánchez, F. J., Montoya, P. (2013): The fossil rodent faunas of the localities Alcoy 2C and 2D (Alcoy Basin, Spain). Implications for dating the classical locality of 2 AlcoyMina. Journal of Iberian Geology 39 (2), 261-284. doi: 10.5209/ rev_JIGE.2013.v39.n2.42501

Mansino, S., Ruiz-Sánchez, F. J., Freudenthal, M., Montoya, P. (2014): A new approach to the Late Miocene-Early Pliocene forms of the genus Apocricetus. Apocricetus alberti (Rodentia, Mammalia) from Venta del Moro (Cabriel Basin, Spain). Proceedings of the Geologists Association 125, 392-405. doi: 10.1016/j.pgeola.2014.07.002

Mansino, S., García-Alix, A., Ruiz-Sánchez, F. J., Montoya, P. (in press): A new Eliomys from the Late Miocene of Spain, and its implications for the phylogeny of the genus. Acta Palaeontologica Polonica, http://dx.doi.org/10.4202/app.00014.2013

Martín-Suárez, E. (1988): Sucesiones de micromamiferos en la depresión de Guadix Baza. PhD. Thesis, Universidad de Granada, 241 p.

Martín-Suárez, E., Freudenthal, M. (1993): Muridae (Rodentia) from the Lower Turolian of Crevillente (Alicante, Spain). Scripta Geologica 103, 65-118.

Martín-Suárez, E., Mein, P. (1991): Revision of the genus Castillomys (Muridae, Rodentia). Scripta Geologica 96, 47-81.

Martín-Suárez, E., Freudenthal, M., Krijgsman, W., Rutger-Fortuin, A. (2000): On the age of the continental deposits of the Zorreras Member (Sorbas Basin, SE Spain). Geobios 33, 505-512.

Mein, P., Freudenthal, M. (1971): Une nouvelle classification des Cricetidae (Mammalia, Rodentia) du Tertiaire de 1'Europe. Scripta Geologica 2, 1-37.

Mein, P., Moissenet, E., Adrover., R. (1990): Biostratigraphie du Néogène Supérieur du basin de Teruel. Paleontologia i Evolució 23, 121-139.

Michaux, J. (1969): Muridae (Rodentia) du Pliocène supérieur d'Es- pagne et du Midi de la France. Palaeovertebrata 3, 1-25.

Minwer-Barakat, R. (2005): Roedores e insectivoros del Turoliense Superior y el Plioceno del sector central de la Cuenca de Guadix. $\mathrm{PhD}$. Thesis, Universidad de Granada, 606 p.

Minwer-Barakat, R., García-Alix, A., Martín-Suárez, E., Freudenthal, M. (2005): Muridae (Rodentia) from the Pliocene of Tollo de Chiclana (Granada, southeastern Spain). Journal of Vertebrate Paleontology 25 (2), 426-441. doi: 10.1671/0272-4634(2005)025[0426:mrftpo]2. 0. co;2

Minwer-Barakat, R., García-Alix, A., Martín-Suárez, E., Freudenthal, M. (2009a): Late Turolian micromammals from Rambla de Chimeneas-3: considerations on the oldest continental faunas from the Guadix Basin (Southern Spain). Neues Jahrbuch für Geologie und Paläontologie Abhandlungen 251 (1), 95-108.

Minwer-Barakat, R., García-Alix, A., Agustí, J., Martín-Suárez, E., Freudenthal, M. (2009b): The micromammal fauna from Negratín-1 (Guadix basin, Southern Spain): new evidence of African-Iberian mammal exchanges during the late Miocene. Journal of Paleontology 83 (6), 854-879. doi: 10.1666/09-009.1.

Minwer-Barakat, R., García-Alix, A., Martín-Suárez, E., Freudenthal, M. (2010): Soricidae (Soricomorpha, Mammalia) from the Pliocene of Tollo de Chiclana (Granada, Southeastern Spain). Journal of Vertebrate Paleontology 30, 535-546. doi: http://dx.doi. org/10.1080/02724631003622001

Minwer-Barakat, R., García-Alix, A., Martín-Suárez, E., Freudenthal, M. (2011): Validation of the Species Stephanomys progressus, a Murid (Rodentia) from the Early Pleistocene of Spain. Journal of Paleontology 85 (2), 392-394. doi: http://dx.doi.org/10.1666/10-131.1

Minwer-Barakat, R., García-Alix, A., Martín-Suárez, E., Freudenthal, M., Viseras, C. (2012): Micromammal biostratigraphy of the Upper Miocene to lowest Pleistocene continental deposits of the Guadix basin, southern Spain. Lethaia 45, 594-614. doi: 10.1111/j.15023931.2012.00324.x

Montoya, P., Morales, J., Robles, F., Abella, J., Benavent, J. V., Marín, M. D., Ruiz-Sánchez, F. J. (2006): Las nuevas excavaciones (19952006) en el yacimiento del Mioceno final de Venta del Moro, Valencia. Estudios Geológicos 62, 313-325.

Morales, J. (1984): Venta del Moro: su macrofauna de mamiferos y bioestratigrafia continental del Mioceno terminal mediterráneo. $\mathrm{PhD}$. Thesis. Universidad Complutense de Madrid, $340 \mathrm{p}$.

Morales, J., Montoya, P., Abellá, J. (2011): Venta del Moro: un yacimiento clave para conocer la historia del límite Mio-Plioceno en el área mediterránea. Paleoisurus 4, 60-71.

Morales, J., Peláez-Campomanes, P., Abella, J., Montoya, P., Gibert, L., Scott, G., Cantalapiedra, J.L., Sanisidro, O. (2013): The Ventian mammal age (Latest Miocene): present state. Spanish Journal of Palaeontology 28 (2), 149-160.

Popov, V.V. (2003): Late Pliocene Soricidae (Insectivora, Mammalia) from Varshets (North Bulgaria). Acta Zoologica Cracoviensia 46, 43-72.

Raynal, J. P., Lefèvre, D., Geraads, D., El Graoui, M. (1999): Contribution du site paléontologique de Lissasfa (Casablanca, Maroc) à une nouvelle interprétation du Mio-Pliocène de la Méseta. Comptes Rendus de l'Académie des Sciences, Series IIA, Earth and Planetary Science 329 (8), 617-622.

Reumer, J. W. F. (1984): Ruscinian and Early Pleistocene Soricidae (Insectivora, Mammalia) from Tegelen (The Netherlands) and Hungary. Scripta Geologica 73, 1-173.

Reumer, J. W. F., van den Hoek Ostende, L. W. (2003): Petauristidae and Sciuridae (Mammalia, Rodentia) from Tegelen, Zuurland, and the Maasvlakte (the Netherlands). In: Reumer, J.W.F. and Wessels, W. (eds.), Distribution and migration of Tertiary mammals in Eurasia. A volume in honour of Hans de Bruijn. Deinsea 10, pp. 455-467.

Robles, F. (1970): Estudio estratigráfico y paleontológico del Neógeno 
del río Júcar. PhD. Thesis, Universidad de Valencia, $275 \mathrm{p}$.

Ruiz Bustos, A., Sesé, C., Dabrio, C., Peña, J.A., Padial, J. (1984): Geología y fauna de micromamíferos del nuevo yacimiento del Plioceno inferior de Gorafe-A (depresión de Guadix-Baza, Granada). Estudios Geológicos 40, 231-241.

Ruiz-Sánchez, F. J., Santisteban, C., Crespo-Roures, V. D., Freudenthal, M. (2011): New rodent faunas from Middle Miocene and Mio-Pliocene in the Cabriel Basin (Valencia, Spain). Journal of Iberian Geology 37, 161-172. doi: 10.5209/rev_JIGE.2011.v37.n2.5

Ruiz-Sánchez, F. J., Freudenthal, M., Mansino, S., Crespo-Roures, V. D., Montoya, P. (2014): Apocricetus barrierei (Rodentia, Mammalia) from La Bullana 2B and La Bullana 3 (Cabriel Basin, Valencia, Spain). Revision of the Late Miocene-Early Pliocene forms of the genus Apocricetus. Paläontologische Zeitschrift 88, 85-98. doi: 10.1007/s12542-013-0178-0

Sesé, C. (1989): Micromamíferos del Mioceno, Plioceno y Pleistoceno de la cuenca de Guadix-Baza (Granada). In: M. T. Alberdi y F. P. Bonadonna (eds.). Geología y Paleontología de la Cuenca de GuadixBaza. Trabajos sobre Neógeno-Cuaternario 11, pp. 185-213.

Sesé, C. (2006): Los roedores y lagomorfos del Neógeno de España. Estudios Geológicos 62, 429-480.

Weerd, A. van de (1976): Rodent faunas of the Mio-Pliocene continental sediments of the Teruel-Alfambra region, Spain. Utrech Micropaleontological Bulletins, special publication 2, 1-217.

Weerd, A. van de (1979): Early Ruscinian rodents and lagomorphs (Mammalia) from the lignites near Ptolemais (Macedonia, Greece). Proceedings Koninklijke Nederlandse Akademie van Wetenschappen $B$ 82, 127-170. 